\title{
The GoOd, The BAD AND THE LuCKY: CEO PAY AND SKILL ${ }^{*}$
}

\author{
ROBERT DAINES \\ VINAY B NAIR \\ LEWIS KORNHAUSER ${ }^{* * *}$
}

FIRST VERSION: NOVEMBER 2004

THIS VERSION: FEBRUARY 2005

\footnotetext{
${ }^{*}$ We thank Bill Allen, Heitor Almeida, Yakov Amihud, Martijn Cremers, Ron Gilson, Kose John, Paul Oyer, Roberta Romano, Antoinette Schoar and Geoff Tate, as well as workshop participants at Berkeley, British Columbia, University of Alberta, and Stanford for helpful comments and discussion; and Jinghua Yan for excellent research assistance.

${ }^{* *}$ Daines is from Stanford University; Nair is from the Wharton School at the University of Pennsylvania; and Kornhauser is from the New York University Law School.
} 


\title{
'The GoOd, The BAD AND THE LUCKY: CEO PAY AND SKILL
}

\author{
Robert Daines \\ Vinay B. Nair \\ Lewis Kornhauser
}

\begin{abstract}
CEO compensation varies widely, even within industries. In this paper, we investigate whether differences in skill explain these differences in CEO pay. Using the notion that skilled CEOs are more likely to continue prior good performance and to reverse prior poor performance, we develop a new methodology to detect if skill is related to pay. We find that highly paid CEOs are more skilled than their industry counterparts when firms are small, especially when there is a large shareholder and the CEO has high incentives, or when firms face few environmental constraints on managerial discretion. By contrast, pay is negatively related to skill in firms constrained by environmental conditions, especially when there is no large shareholder to monitor management or the firm is large. We also examine CEO turnovers and show that the firm's post-turnover performance is related to differences between the two CEO's pay levels. Finally, we find that a portfolio that invests in firms managed by highly paid CEOs and sells firms managed by poorly paid CEOs generates an annualized abnormal return of $8 \%$ between 1994 and 2001, but only in conditions when pay and skill are related.
\end{abstract}


One of the great, as-yet-unsolved problems in the country today is executive compensation and how it is determined.

Securities and Exchange Commission chairman, William H. Donaldson ${ }^{1}$

Is it a problem of bad apples, or is it the barrel?

Harvard Business School Dean, Kim Clark ${ }^{2}$

\section{PART I. INTRODUCTION}

Very few business topics are as hotly contested as the salaries of CEOs of public firms. The amount that CEOs are paid and the structure of their pay is frequently debated in the popular press, television programs, proposed legislation, political campaigns, magazine cover stories and academic research. Outrage over CEO pay has forced important changes at major firms; Jack Welch of GE was forced to give back part of his pay when investors complained it was excessive and Richard Grasso of the NYSE was forced to resign altogether.

One obvious reason for the interest in CEO pay is its striking increase. In 1992, the average CEO of an S\&P 500 firm earned $\$ 2.7$ million. By its peak in 2000, average pay for these CEOs had increased to over $\$ 14$ million - an increase of more than $400 \%$. The increase in CEO pay is even more striking in relative terms. 12 years ago, CEOs at major U.S. corporations were paid 82 times the average earnings of a blue collar worker; last year they were paid more than 400 times the average blue collar worker. This huge increase in executive compensation has been especially controversial because CEOs are sometimes paid large sums even as the firm's results deteriorate; CEOs at WorldCom, Tyco, and Enron, collected over $\$ 100$ million on average in the year prior to the scandals at or collapse of their firms.

These facts and spectacular governance failures at important firms have caused many to conclude that the process for setting CEO pay and, more generally, the governance of public firms is badly broken.

\footnotetext{
${ }^{1}$ National Press Club speech, August 2003

${ }^{2}$ National Press Club speech, February 2003
} 
Critics such as Bebchuk and Fried (2004) conclude that CEOs are overpaid because they have too much influence over the board that should be monitoring them on shareholders' behalf and too much influence over the committee that sets their pay. Independent directors and consultants hired to advise the board have relatively little interest in safeguarding shareholder interests. Thus, CEOs are effectively able set their own pay and the CEO's compensation contract is badly distorted. In this view, CEO pay is the product of badly functioning corporate governance. Such arguments also suggest that cases of excessive CEO pay reflect a systematic social problem of "fat-cat" CEOs skimming money at shareholders' expense and therefore a systematic breakdown of governance

Others are more sanguine, arguing that the process for determining CEO pay is not systematically broken. Holmstrom and Kaplan (2003) argue that US corporate governance works relatively well and that any problems with CEO pay have not erased the comparative advantages of the U.S. system. ${ }^{3}$ Murphy (2002) argues that CEO pay levels and practices are generally consistent with good governance and that distortions from optimal contracting reflect the perceived impact of accounting and tax rules. In this view, compensation problems reflect breakdowns in particular firms, but do not indicate a general problem in compensation or in public firm governance generally.

Previous research seeking to distinguish between these competing views of CEO pay typically examines whether CEO pay changes with contemporaneous changes in firm performance. Agency theory suggests that the CEO pay should be linked to changes in firm value in order to align managers' interests with shareholders. ${ }^{4}$ To the degree pay doesn't change with performance, deviations are taken as evidence of CEO skimming excessive compensation.

Surprisingly, however, there is little evidence on the basic question: is CEO pay related to CEO skill? Are highly paid CEOs better than their more poorly paid peers? The question is not only important in

\footnotetext{
${ }^{3}$ Reasons other than governance failures may explain the increase in pay unrelated to performance. For example, Murphy and Zabojnik (2004), Oyer (2004), and Himmelberg and Hubbard (2002) argue that CEO pay reflects changes in labor market for CEOs. Bolton et al. (2003) argue that it may even be in shareholders' interest to avoid incentive pay if capital markets are speculative.

${ }^{4}$ There are several papers that investigate factors, such as risk, that affect the optimal amount of incentive pay. See Murphy (1999) and Core, Guay and Larcker (2001) for a survey of this literature.
} 
evaluating the appropriateness of CEO pay levels but also in evaluating the governance of public firms. If pay and skill are related, high salaries will not necessarily be evidence that "fat cat" CEOs capture the board. Just as sports teams may decide to pay high salaries to attract or retain valuable players, boards may also pay more for especially talented managers. If, on the other hand, pay and skill are unrelated, the process for setting CEO pay is likely to be badly broken and highly paid CEOs may be over-paid, regardless of which model describes the process of setting executive compensation.

To examine whether pay and skill are linked, we introduce a new measure of skill. The intuition behind our measure of skill is straightforward: firms run by good CEOs should consistently do better than firms run by bad CEOs. If a firm has been performing poorly relative to its peers, a skilled CEO will consistently be more likely to reverse the firm's fortunes, while a bad CEO will be more likely to continue the poor performance. If, on the other hand, a firm has been performing well relative to its peers, a good CEO will consistently be more likely to continue the good performance, while a bad CEO will increase the chance of a bad outcome. Thus, good CEOs will reverse poor performance and continue positive performance. "Bad" CEOs continue poor performance and reverse positive performance. "Lucky" CEOs are highly paid, but perform no differently from their lower-paid peers.

Our measure of skill - the persistence of positive performance and the reversal of poor performance -- is related to the performance persistence measure used to evaluate skill among mutual fund managers (Brown and Goetzman, 1995), hedge fund managers (Brown, et al, 1999) and investment analysts (Mikhail, Walter and Willis, 2004), but has several advantages for studying industrial firms and CEOs.

First, by conditioning on past performance, we compare CEOs to other CEOs in the same position. Because a firm's opportunities may be a function of past performance, we thus avoid comparing a CEO who is in charge of a firm that performed well in the past with another CEO who is in charge of a firm that performed poorly. 
Second, this method allows us to avoid some of the econometric problems that have affected prior research. One reason that prior research has not previously examined the relationship between CEO pay and CEO skill is that it is difficult to separate CEO effects from firm effects. Bertrand and Schoar (2004) deal with this by examining CEOs who move from one firm to another. This methodology helps them to distinguish the styles of particular CEOs, but for much of the analysis restricts the sample to roughly 117 CEOs (out of around 500 top executives) that switched firms, and these CEOs who switch firms may be different from CEOs who do not change firms. While our methodology does not explicitly separate the effects of individual CEOs, it does reduce such concerns. As discussed in Part 2, any identified skill will likely be related to the CEO rather than simply to the firm. Thus, our method allows us to consider a large sample of public firms, which is useful given that the design of CEO pay is said to be systematically broken, and to be worse in firms when the CEO is entrenched and thus hasn't moved.

A third advantage of the methodology is that we are able to to distinguish between "good," "bad" and "lucky" CEOs rather than simply examining whether there is persistence in general. This allows us to make some initial conclusions about overall pay levels, something that is generally difficult to do. However, we can conclude that highly paid CEOs are overpaid if their performance is consistently worse than their lower-paid peers.

We begin by examining overall CEO pay levels. In a functioning labor market, a CEO's reservation wages and pay level might be increasing with a CEO's outside opportunities, skill or marginal product. This variation in skill may explain some of the variation in CEO pay. We use the pay levels in the year prior to the realized performance year to see if the pay captures the expectations of CEO skill. We then look at subsequent realized performance to see if the pattern is consistent with the idea that highly paid CEOs are more skilled.

We find evidence that highly paid CEOs are more skilled when firms are small or when there are fewer environmental constraints on managerial discretion. This link between pay and skill is especially strong if there is a blockholder to monitor management of if the CEO receives performance-based pay. By 
contrast, we find that highly paid CEOs who operate in large firms subject to environmental constraints perform worse than their more poorly-paid peers - they are more likely to continue poor performance and surprisingly, even to reverse good performance. This negative relation between pay and skill is exacerbated in the absence of a large shareholder to monitor management.

We also investigate the importance of performance-based pay in the link between pay and skill. We find that in firms where there is a link between pay levels and skill, the link is stronger when performance-based pay is more important, especially if the higher pay is accompanied with the presence of an external blockholder. We also find evidence that the presence of an external monitoring shareholder strengthens the link between pay levels and skill. This suggests that the level of pay may itself be an important incentive. When CEO's can be dismissed for poor performance, relatively well-paid CEOs will find dismissal more costly than those CEOs that are relatively poorly paid, therefore the pay level itself can act as performance-based pay. Another possibility, consistent with Bertrand and Mullainathan (2001), is simply that excessive CEO pay is more likely in the absence of monitoring shareholders.

In addition, we find that a new $\mathrm{CEO}$ who gets a higher pay than the departing $\mathrm{CEO}$ is more likely to reverse prior poor performance, relative to CEOs who are paid similarly or lower than the departing CEO, if the pay package is performanced-based. Strikingly, if the highly paid new CEO's pay is not performance-based, the CEO is more likely to continue prior poor performance.

Finally, we create equal-weighted portfolios that hold firms with highly paid CEOs and shorts firms with low paid CEOs. ${ }^{5}$ When pay and skill are related, we find that such a portfolio generates an annualized abnormal return of $8 \%$ between 1994 and 2001. When pay and skill are unrelated, there is no such abnormal return. The mean return of firms in which pay and CEO performance are linked exceeds the mean return of firms in which pay and CEO performance are not linked by almost $8 \%$.

Part II describes our data and methodology. Part III describes our findings on the connection between pay and skill and examines how this connection varies with industry specific constraints on the

\footnotetext{
${ }^{5}$ We focus on equal-weighted portfolios since we find that CEOs are more important in smaller firms.
} 
CEO's discretion. Part IV examines the affect of performance-based pay on the link between pay and skill.

Part V computes the returns to the portfolio that buys firm's managed by highly-paid CEOs and shorts firms managed by poorly-paid CEOs in industries where skill and pay are linked. Part VI concludes.

\section{PART II. DATA AND METHODOLOGY}

In this section, we present the methodology we use to detect whether CEO skill and pay are related. We assume that CEO skill will manifest itself in firm performance and that highly skilled CEOs will lead to better results. A talented CEO who either does not exert effort or is unable to affect firm performance would not be classified as skilled. Our approach then follows: if pay and skill are related, current compensation will be related to future performance. If CEO pay levels are unrelated to CEO skill, then current compensation will be unrelated to future performance.

It is worth noting at the outset that our approach differs from the vast majority of research on CEO pay. Most prior research examines the structure and design of CEO pay or, in other words, the relationship between pay and contemporaneous performance. ${ }^{6}$ By contrast, we examine total pay and its relation to future firm performance. Thus, while the prior literature typically uses firm performance as the independent variable and the CEO's pay as the dependent variable, we use prior future firm performance as the dependent variable and the CEO pay as an independent variable.

Since we are interested in detecting if pay levels are related to CEO skill, we estimate the following regression:

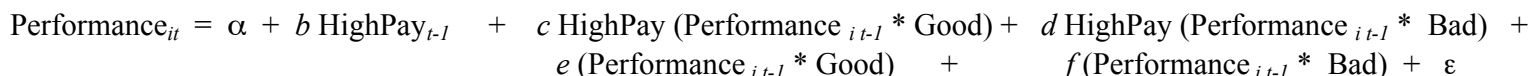

where Performance $_{i t}$ is the measure of the firm's performance, $\alpha$ is a constant, HighPay is a dummy variable set equal to 1 if the CEO pay was in the top $40 \%$ of the industry the prior year, equal to 0 if the CEO pay was in the bottom $40 \%$ of the industry, and otherwise set to missing, and good (bad) is a dummy

\footnotetext{
${ }^{6}$ An important exception, discussed in Part 5, is Hayes and Schaefer (2000). If boards observe and reward a CEO's contribution before the market does, then regressing current pay on future performance will not capture CEO skill: current high pay and future good performance might just reflect good current firm performance and good current performance may not be related to CEO skill, but luck. Also Hallock and Oyer (1999).
} 
variable set equal to one if the firm's performance that year was better (worse) than the industry median. ${ }^{7}$

We control for median pay levels, rather than other factors that may be associated with high pay (such as as age, tenure, and experience) because we are interested in whether pay levels are linked to skill, rather than to detect, or make assumptions on the potential sources of variation in skill.

Since two firms that have performed differently in the past might have very different possibilities in the future, we condition the persistence on prior performance being above industry median or below industry median levels. This insures that we compare CEOs managing firms with similar prior results.

Conditioning on prior performance has another advantage. It is possible (and likely) that there are firm specific factors that increase both pay and persistence in prior performance. For instance, it might be the case that large firms have both a higher pay and, due to inertia, have greater overall performance persistence. We mitigate - but do not completely remove - such concerns by defining skill as the persistence of superior performance as well as the reversal of poor performance (or turnarounds) for the highly paid CEOs. ${ }^{8}$ We interpret this pattern of continuing positive performance and reversing negative performance as consistent with CEO skill. The alternative interpretation would be that some firm factor (unrelated to the CEO's actions and skill) is correlated with high pay, reversals of bad performance and persistence of good performance. We are unable to think of a plausible such factor. ${ }^{9}$

In terms of the regression, we therefore look for both a significant positive coefficient for highly paid CEOs given prior good performance $(c)$ and a significant negative coefficient for highly paid CEOs given prior bad performance $(d)$. A skilled CEO will have a negative (rather than a positive) coefficient

\footnotetext{
${ }^{7}$ We also define highly paid CEOs as those in the top $20 \%$ of the industry with similar results.

${ }^{8}$ For instance, momentum in stock prices will not explain any observed skill. It is true that stock price momentum might lead to performance persistence for CEOs whose compensation were related to the firm's stock price, however we define skill as performance persistence when the firm's prior performance was good, and reversals (rather than momentum) if the prior performance was bad. This pattern of reversals will be inconsistent with explanations based on momentum. Also note that any survivorship bias will only explain observed skill if the most highly paid CEOs are more likely to fail and thus disappear from the sample, thus exaggerating the good performance the next year. This seems unlikely.

${ }^{9}$ One potential objection is that, by conditioning on prior poor performance, we might identify some as skilled who has only done well relative to poor performers, which is too low a standard for calling someone skilled. However, because we condition both on good and bad performance, highly paid CEOs will need to do well consistently (following good years and following bad years) to be identified as skilled. Moreover, a CEO who does consistently better other poor performing CEOs will eventually emerge out of the poor performing category.
} 
following bad years because the firm's performance is actually negative in bad years, since we subtract the industry median from each firm's performance. Therefore, in order to turn the firm around and produce positive results, a skilled CEO should have a negative coefficient on the prior (negative) bad performance. Thus, a positive estimated coefficient following good years and a negative estimated coefficient following bad years would indicate that, compared with poorly paid CEOs, highly paid CEOs are both more likely to continue good performance and more likely reverse prior bad performance.

We also examine how the relationship between pay and skill varies in different settings. For instance, we would expect a stronger link between CEO pay and skill when CEO's are likely to have a greater impact on the firm (recall that our notion of skill combines impact on firm performance and the CEO's innate ability or talent). It has been argued that environmental constraints, such as regulation, can reduce the impact of the CEO (see, e.g., Hambrick (1995), Adams et. al. (2004)). So we also estimate the regressions separately based on environmental constraints. It is also argued that CEO's are more likely to impact firm value when their pay depends on firm performance. Consequently, we estimate the above regression based on the incentive component in pay.

We first compute CEO pay, defined as the sum of the cash, bonus payments, option grants and stock grants. We then compute industry adjusted pay-levels for all CEOs by subtracting the median CEO pay in the same industry, using the 48 industry classification provided by Fama-French (1997). We then sort the CEOs in pay-quintiles based on industry adjusted overall pay and classify CEOs as highly paid if they are in the top 2 pay quintiles for their industry (the top $40 \%$ ).

As a measure of firm performance, we first use return on assets. Since accounting measures might be subject to manipulation by the CEO, we also measure the firm's stock price performance because stock prices are less likely to be affected by cosmetic earnings changes that do not affect the firm's cash flow. For stock price performance, we compute the yearly abnormal return for each firm in the sample using daily data. The abnormal return is computed for the Fama-French four factor model that includes the market factor, size factor, book to market factor and the momentum factor. Both of these measures of 
performance are computed relative to the firm's industry, where industry adjustments are done using both the 2-digit SIC classifications as well as the 48 industries classified by Fama and French. ${ }^{10}$ To reduce the noise in these yearly abnormal returns we (1) use daily returns and (2) form quintiles based on a firm's measure of abnormal returns, making it less likely that our results are driven solely by noise in measures of return. ${ }^{11}$ If investors accurately assess and anticipate the CEO's skill level, there will be no measurable link between skill level and stock return.

We include in our sample all firms for which we can find data on stock return data on CRSP, accounting data on Compustat, and compensation data on Execucomp for the years 1992-2001. This produces a sample of 12,569 firm years, in which there are 2,373 unique firms and 3,579 unique CEOs. In regressions reported below, we exclude firms if there is a turnover either that year or in the previous year. This insures that we focus on the same CEO and do not use the performance of one CEO to estimate the performance of another. In the resulting no turnover sample, we examine 2,284 firms and 2,880 CEOs (10,043 firm years). The turnover sample, used as described below, contains 980 firms.

Table 1 below provides summary data for our sample. Panel A lists descriptive statistics. Mean CEO pay in our sample is 4.39 million, of which $46 \%$ is characterized as performance-based. ${ }^{12}$ The top five spots are occupied by Charles Wang of Computer Associates (\$1.3 billion in 1998), Steve Jobs of Apple (\$600 million in 2000), Gregory Reyes of Brocade (\$370 million in 2001) and Thomas Siebel of Siebel (\$293 million in 2000, and \$244 million in 2001). On the other end of the scale were 18 CEOs who received no pay.

Variation in CEO pay is large, with a standard deviation in our sample of roughly $\$ 18$ million. Figure 1a provides detailed information by industry. The difference between CEOs paid at the 80th percentile and those paid at the $20^{\text {th }}$ percentile ranges from $\$ 682,000$ in coal and $\$ 1.8$ million in utilities (on

\footnotetext{
${ }^{10}$ Since the abnormal returns vary in their statistical significance, the industry average is computed as a weighted average where the weights are proportional to their t-statistics. This ensures that abnormal returns that are not statistically significant are weighted less.

${ }^{11}$ Our results are qualitatively similar when we use the abnormal returns directly instead of quintiles and are omitted here. We also find similar results when we use an ordered logistic regression to estimate return quintiles.

${ }^{12}$ For a measure of incentive pay, we use ((total pay-salary-bonus)/total pay).
} 
the low side) to $\$ 16$ million in Telecom and nearly \$29 million in Fabricated Products and Machinery (on the high side). As evident in Figure 1b, the standard deviation in CEO pay is closely connected to the industry average pay. Note that there is very little between industry variation in the fraction of CEO pay that is performance-based - even as average pay increases, the incentive fraction remains relatively flat at between $35 \%$ to $50 \%$ of total CEO pay.

Panel B of Table 1 reports correlation coefficients between the main variables of interest. CEO pay is positively correlated with firm size and with the fraction that is performance-based, as expected. Our proxy for shareholder monitoring of CEO performance, the existence of a $5 \%$ blockholder, is negatively correlated with total CEO pay, and positively correlated with the fraction that is performance-based. In addition, firms operating with few environmental constraints have both more blockholders and pay that is more tied to performance.

[Insert Table 1 and Figure 1 about here]

\section{PART III THE LINK BeTWEen CEO PAY AND SKILL}

We first estimate a pooled-sectional regression estimating performance persistence and reversals for all firms in our sample. The estimated regression coefficients are reported in Table $2 .{ }^{13}$ We find that, when compared to poorly paid CEOs, highly paid CEOs are significantly more likely to exhibit consistently good performance. However, we find no difference with regard to reversals and high CEO pay. Not surprisingly, we also find performance persistence generally. ${ }^{14}$

Since we only find a link between pay levels and positive persistence, we cannot say whether CEO pay and skill are in general linked. The association between a higher CEO pay and greater positive persistence could be due to firm factors associated with both high pay and persistence generally. One such firm characteristic could be firm size. Large firms might have both more inertia in performance and higher

\footnotetext{
${ }^{13}$ The statistical significance of the results presented in the paper are robust to clustering of standard errors by firm.

${ }^{14}$ Here, as later, we find a negative coefficient on the high pay dummy, which might be taken to suggest that highly paid CEOs perform worse. However, in our regressions finding skill, this effect is outweighed by the superior positive persistence and reversals effect of highly paid CEOs unless the firm's performance is close to the industry median. This indicates that pay and skill are related especially when the firm's performance is significantly different from the industry median, as one might expect.
} 
CEO pay; large firms, like large ships, may take time to turn around. So we examine the link between pay and skill for large and small firms. Firms are classified as large if their asset size is greater than the median asset size of the sample. Such a classification also sheds light on whether the impact of a CEO might vary with firm size.

We find evidence that among small firms highly paid CEOs are more skilled than their more poorly paid peers. See Table 2 below. In small firms, highly paid CEOs are significantly more likely to continue positive performance and to reverse poor performance than poorly paid CEOs, using both accounting and stock market measures of performance. The effects are large; a highly paid CEO is more likely continue positive ROA (estimated coefficient 0.11 ) and to reverse poor performance (estimated coefficient -0.17$){ }^{15}$ The persistence of abnormal returns associated with highly paid CEOs in small firms is significant as well (0.17 higher following a good year, and 0.35 lower following a bad year.) As discussed earlier, this pattern of positive persistence and reversals of poor performance suggests a link between high pay and managerial skill and mitigates concerns that firm specific factors drive persistence. By contrast, in large firms, there is no evidence that highly paid CEOs produce predictably better results; the estimated coefficients for highlypaid CEOS are all insignificant. ${ }^{16}$

These results suggest two possibilities: (1) consistent with Jensen and Murphy (1990), CEOs have a greater impact in smaller firms or (2) the design of compensation is faulty in large firms. We now investigate if the link between pay and skill varies with factors that affect the CEO's impact on the firm.

[Insert Table 2 about here]

\footnotetext{
${ }^{15}$ See Part VI for an estimate of the economic impact of a highly paid CEO.

${ }^{16}$ [vinay: I added this footnote:One could argue that the CEO's effect may only be felt over a longer time-frame. Consequently, we examined whether our main results were robust to longer time frames (i.e. 2 years), and found similar, but less significant, results to those reported here. An alternative view would be to view the speed of change as an outcome of CEO skill.
} 


\section{A. ENVIRONMENTAL CONSTRAINTS}

Our ability to detect CEO skill may depend on the environment in which the firm operates. If regulatory or environmental constraints limit a CEO's discretion and alternatives, it may be difficult for the CEO to affect firm performance (Finkelstein and Hambrick, 1996; Hannan and Freeman, 1977). Hambrick and Finkelstein (1987) argue that managerial discretion can be limited by environmental factors such as regulation, competition, the degree to which the firms' products are differentiable from its competitors, and the existence of large concentrated suppliers or customers. Hambrick and Abrahamson (1995) use a panel of industry analyst, academics and industry-level data to rank environmental constraints on managerial discretion. Industries classified as high constraint using this measure include natural gas transmission, electric services, oil, utilities, textiles, books, transportation, paper, and ships, while industries characterized as low environmental constraint include electrical equipment, health, chips, computers, drugs, banks, beer, insurance, medical equipment and personal services. Using this measure of environmental constraint on managerial discretion, Adams et. al. (2004) show that environmental constraints indeed limit a manager's ability to affect firm performance.

We use this variable to examine how the link between pay and skill varies with constraints on managerial discretion. Where environmental factors limit discretion, CEOs are more likely to perform similarly even if they have different innate talents and therefore CEO skill will be less correlated with pay. By contrast, when the CEO faces fewer environmental constraints the link between pay and skill should be stronger because skilled CEOs will be able to induce a greater variation in firm performance and, to the degree skill and pay are linked, we will more easily observe the correlation.

Since the data are likely to be noisy, we use an indicator variable set equal to one for firms in industries ranked in the top 50\% of the distribution (high constraint industries), and equal to zero for industries in the bottom $50 \%$ of the distribution (low constraint industries).

We separately estimate the regression for firms in high and low constraint environments. As reported in Table 3 below, we find that high CEO pay is clearly associated with better performance in 
industries characterized by low constraint on managerial discretion. In measures of both accounting performance and abnormal returns, firms managed by highly paid CEOs were significantly more likely to continue good performance (the estimated effect on ROA is an additional 0.24 , significant at $1 \%$ ) and less likely to continue bad performance (the estimated coefficient is -0.17 , significant at $5 \%$ ). Results using abnormal returns are similar; estimated persistence for abnormal returns for highly paid CEOs is 0.24 higher following a good year (significant at $1 \%$ ) and - 0.17 following poor performance (significant at $5 \%$ ).

By contrast, in high constraint industries, there is little evidence of high skill among highly paid CEOs. Highly paid CEOs in industries where managers have little discretion perform no differently from their lower-paid peers following a bad year. The evidence is mixed for performance following a good year: firms managed by highly paid CEOs in these industries have superior accounting results are indistinguishable in terms of the abnormal returns. Given the lack of reversals of negative performance and the inconsistent evidence of positive persistence, we conclude that there is no evidence that CEO skill and pay are linked in firms where environmental constraints limit managerial action.

[Insert Table 3 and Figure 2 about here]

This relationship between pay and the quality of the performance persistence can be seen across pay categories. Figure 2 separately reports estimated performance persistence coefficients CEOs in each pay quintile. We divide the sample into quintiles and run the regression on each quintile. In low constraint industries, the correlation between good performance last year and performance this year generally increases with CEO pay. The slope of the line is positive and increasing in pay quintile. When the prior year's performance was bad, there is less and less performance persistence as pay quintiles increase, and the slope of the line is negative indicating that more highly paid CEOs were better able to reverse poor performance persistence following bad years. When we consider only firms in high constraint industries, this pattern is reversed. As we move up the pay scale in these firms, bad years are more likely to predict 
future performance and good years less likely. By contrast, there is no particular pattern for firms in firms where industry factors constrain managerial discretion.

Given that we earlier found differences based on firm size, we separately examine the impact of environmental constraints for big and small firms (again characterized by median industry adjusted size). We separately estimate the regression for each subgroup. Table 4 reports estimated coefficients only on the variables we look to for evidence that skill and pay are connected: positive persistence and reversals for highly paid CEOs. For the balance of the paper, we report only these estimated coefficients and omit the estimated coefficients for the constant, the highly paid CEO dummy and the interaction terms from the basic model described in Part II.

As reported in Table 4 below, there is little evidence of high skill among big firms and if anything there is some evidence that pay and skill are negatively related in the accounting performance big firms where the CEOs actions are constrained by environmental factors. Highly paid CEO in these environments are significantly more likely to reverse positive accounting performance (the estimated coefficient is -0.38 ) and to continue poor performance (the estimated coefficient is .21). The differences are economically meaningful and statistically significant at the $1 \%$ and $5 \%$ level respectively. As before, we observe reversals in firms facing few environmental constraints, but do not observe the persistence of positive performance. Abnormal returns show no evidence of skill for big firms.

By contrast, pay is more closely connected with skill in small firms. Using abnormal returns as the performance measure, highly paid CEOs in low constraint environments show both significantly more positive persistence and significantly more reversals when the firm is small (the estimated coefficients are 0.18 for positive performance persistence and -0.27 for reversals of poor performance). In small firms in high constraint environments, highly paid CEOs are no more likely to exhibit positive persistence, but reversals continue to be significantly more common (the estimated coefficient is -0.28). Using ROA as the performance measures, the estimated positive persistence is 0.41 , while big firms in the same industry saw reversals following positive performance (estimated coefficient -0.38) and the persistence of bad results. 
Thus, there is no consistent pattern in high constraint environments, though there is some evidence that pay and skill are negatively related in big firms in constrained environments. We interpret these results as consistent with the idea that CEO skill is more tightly linked with pay in industries in which CEOs are likely to have a greater impact on firm performance. Moreover, when industry factors constrain CEO discretion, there is some evidence that small firms exhibit a tighter link between pay and skill than do big firms.

\section{[Insert Table 4 about here]}

\section{B. THE IMPORTANCE OF EXTERNAL FACTORS}

We next examine the connection between pay and skill in environments where firm specific factors are important for firm performance. To compute the relative importance of external factors vis-à-vis firm factors in performance, we compute within industry variations of analyst forecasts from IBES. To do this, we use the average earnings forecast for each firm and then compute the variation in the average earnings forecast for different industries. In industries where all firms have similar forecasts, firm specific factors are likely to be less important for performance. In contrast, when there is a large variation among firms within the same industry there is the potential for firms to perform very differently.

We then examine the link between pay and skill for different levels of the computed firm-specific dispersion. We find that the results are largely consistent with the results on skill and pay by environmental constraints. ${ }^{17}$ Highly paid CEOs are significantly more likely to both perform consistently well and to reverse poor performance in environments where external factors are less important.

[Insert Table 5 about here]

\footnotetext{
${ }^{17}$ The correlation between the proxy for environmental constraints and uncertainty is significant, but a relatively low 0.16 .
} 


\section{SUMMARY}

We examine variation in CEO pay and find that pay is linked to skill in firms that are small or when firms are subject to few environmental constraints. In these firms, highly paid CEOs are significantly more likely to continue good performance and to reverse negative performance. The estimated effects are economically significant and robust to alternative measures. By contrast, among big firms and firms where the CEO is constrained by environmental or external factors, CEO skill is actually negatively related to pay. In these firms, highly paid CEOs are more likely than their poorly paid peers to continue poor performance and to reverse positive performance. These are our primary empirical findings. Appendix A gives additional detail about highly paid CEOs in firms in which we find, on average, a negative link between pay and skill. The balance of the paper examines the role of performance-based pay, monitoring shareholders and provides some robustness checks.

\section{PART IV THE ROLE OF PERFormance-BaSed Pay}

So far we have examined the relationship between total pay and CEO skill and now turn to the effect of performance-based pay. As discussed in Part II, CEO skill can be viewed as a combination of the executive's innate ability (or talent) and of his effort. Two CEOs with different talent endowments but who exert no effort are more likely to perform similarly than are CEOs who exert different amounts of effort. Thus, since higher performance based pay should induce higher effort, we would expect to find a stronger link between pay and skill when the CEO has greater incentives to exert effort. An alternative account is that performance-based pay is more attractive to highly talented CEOs, in which case we should also observe a greater link between pay and skill when pay is tied to performance.

We examine two measures that affect managerial incentives. First, we examine the link between pay and skill when performance-based pay (stock and option-based compensation) constitutes an important part of the CEO's total pay package. Second, since the threat of termination can provide incentives to exert effort as well, we then investigate if the link between pay and skill is stronger when the threat of dismissal 
for poor performance is higher. We use the existence of a strong shareholder as a proxy for a greater likelihood of dismissal for poor performance. ${ }^{18}$

\section{A. STOCK AND Option BASED PAY}

In this section, we examine the connection between skill and pay among CEOs whose pay is relatively more dependent on stock price performance. We first divide the sample into CEOs with high performance-based pay (defined as those whose fraction of stock-based compensation is above the median level in the same industry) and CEOs with low performance-based pay (stock-based compensation is below industry median). We then run the same regression for firms in each category of performance-based pay. ${ }^{19}$

Consistent with the prediction that pay and skill are more closely linked in the presence of highpowered incentives, we find greater evidence of skill for highly paid CEOs. As reported in Panel A of Table 6 below, among highly incentivized CEOs, highly paid CEOs were more likely to continue superior performance and also more likely to reverse inferior performance than their less richly compensated peers. The effect is statistically significant at $1 \%$ (for ROA measures) and economically meaningful. By contrast, absent high-powered incentives, we find no evidence of differential skill for highly paid CEOs - we find no significant difference in persistence of positive performance and reversals of poor performance. This is consistent with the idea that performance-based pay increases the connection between pay and skill. Stock returns show no such effect.

Since we have seen that the link between pay and skill is stronger in small firms, we further partition the pay performance intensity along dimensions of firm size. As reported in Panel B of Table 6, performance-based pay strengthens the link between pay and skill especially in smaller firms. Using ROA as the measure of performance, CEOs in small firms who are highly paid and have a high incentive

\footnotetext{
${ }^{18}$ See Huson, Parrino and Starks (2000) for evidence that the presence of strong shareholders is associated with greater CEO dismissals. This threat, however, may be less important if severance pay is high.

${ }^{19}$ Analyzing incentive pay also sheds light on a potential interpretation that all agents have same reservation wages but different contracts are offered. More skilled agents choose pay structures with greater incentive pay and hence also get a higher pay level. We think this is unlikely to be the complete story, since there are many CEOs with high pay but not high incentive pay. Moreover, even within an industry, where firms are similar, there are differences in incentive pay and pay levels.
} 
component show evidence of skill - they are significantly more likely to continue good performance (estimated coefficient .51) and to reverse bad performance (estimated coefficient -.54) when they have high-powered incentives. In small firms, the same pattern of highly paid CEOs doing better in the presence of high power incentives holds when we examine firm's stock returns.

Thus, we find that highly paid CEOs with high powered incentives and in small firms are significantly more likely to reverse bad performance and to continue good performance than their more poorly paid peers. By contrast, for CEOs with low powered incentives and for big firms, there is no evidence of skill.

[Insert Table 6 about here]

Before we proceed to investigate the link between pay and skill in the presence of a threat of CEO dismissal, we present one refinement of these results. Bertrand and Mullainathan (2001) have shown that stock and option based pay are not likely to be related to CEO effort in the absence of monitoring shareholders. Thus performance-based pay should perhaps be characterized not simply as high stock and option based pay but as a combination of high stock and option based pay and the presence of an external blockholder. We therefore redo our results on performance-based pay for firms with and without a blockholder, where blockholder is defined as a non-managerial investor holding at least $5 \%$ of the stock.

Generally consistent with Bertrand and Mullainathan (2001), the results suggest that incentives work better in the presence of a blockholder. As reported in Panel C of Table 6, highly paid CEOs with a blockholder and high stock and option-based pay are both more likely to reverse poor performance and to continue good performance than are their less well-paid counterparts (the estimates are significant for the accounting measures and of the right sign but insignificant for stock return measures.) However, highly paid CEOs with high incentives are not likely to continue prior good performance in the absence of a 
blockholder. However, CEOs with high incentives but no blockholder do appear to reverse prior bad performance.

\section{B. MONITORING SHAREHOLDERS}

The threat of termination can act as an incentive device as well. To proxy for a higher threat of dismissal, we use the existence of an external institutional blockholder. To see if such monitoring shareholders increase the link between pay and skill, we check the association between pay levels and CEO skill in firms with and without a blockholder. Table 7 presents the coefficients estimating positive persistence and reversals for highly paid CEOs, broken down by the existence of a blockholder (which we define as the existence of an institutional shareholder with greater than $5 \%$ of the firm's equity) and by firm size. Consistent with the idea that monitoring shareholders improve the connection between pay and skill, we find that in the presence of a blockholder, highly paid CEOs are significantly more likely to reverse prior ROA in both large firms and small firms.

[Insert Table 7 about here]

This is consistent with the idea that, given a monitoring shareholder, total pay (and not just performance-based pay) serves as performance incentive and that pay and skill are linked. An alternative interpretation, however, is simply that the design of CEO pay is more likely to be faulty in the absence of monitoring shareholders. If this were indeed the case, one would expect corrupt CEOs to pay themselves the most in the absence of a monitoring shareholder. If these corrupt CEOs also perform poorly, one would then, in the absence of a blockholder, expect a negative relation between CEO skill and pay. ${ }^{20}$ If, on the other hand, they perform no differently from other CEOs, we would not expect to find, in the absence of a blockholder, any relation between pay and skill. To investigate if there is any such negative relation

\footnotetext{
${ }^{20}$ If the role of the monitoring shareholder is to only incentivize the CEO by a threat of dismissal, there is no reason to expect a negative relation between pay and skill in the absence of such monitoring shareholders.
} 
between pay and skill in the absence of monitoring shareholders, we estimate the regression with and without blockholders and with and without environmental constraints.

The effect of a blockholder appears to be strongest in firms where CEOs face environmental constraints. As reported in Table 7, pay appears to be negatively related to skill in firms without blockholders and in industries with high environmental constraints. Highly paid CEOs in such environments are more likely to reverse positive performance (estimated coefficient is -.21) and to continue bad performance (the estimated coefficient is .35). This pattern of performance appears to most consistent with negative skill and clearly indicates that these CEOs are excessively paid. Further, the negative link between CEO pay and skill also highlights the more general governance role of the blockholder, who likely does more than simply posing a threat of dismissal. ${ }^{21}$

By contrast, firms in industries with high environmental constraints show some evidence that higher pay is connected with better positive persistence if there also a blockholder. The estimated coefficient for continuing positive ROA performance is significant and economically meaningful (the estimated coefficient is 0.21 ). However, absent environmental constraints, it does not appear that blockholders are associated with any differing relation between pay and skill. Thus the governance role of a monitoring shareholder appears more important in industries that face environmental constraints. ${ }^{22} \mathrm{~A}$ more detailed investigation of how all the various aspects of corporate governance affect the link between CEO pay and skill is left for future research.

\section{PART V SKILL AND CEO TURNOVER}

We have seen that pay and skill are correlated in small firms and in firms where managerial discretion is likely to affect firm performance, while pay and skill are negatively correlated in large firms operating in environments that constrain managerial discretion (especially if the firm lacks a blockholder).

\footnotetext{
${ }^{21}$ Alternatively, severance pay is high enough to offset the incentive that arises from dismissal and the pay design role of strong shareholders is more important.

${ }^{22}$ The effects of firm size and the existence of a large shareholder to monitor management reported below are largely similar when we substitute uncertainty for managerial discretion, though the significance levels are reduced in some circumstances.
} 
In this section we use an alternative sample to test if skill and pay are related by examining a firm's performance persistence associated with CEO turnover. Changes in CEOs could be associated with changes in CEO skill. If pay is indeed related to skill, pay levels should then also be different.

Consequently, we would expect that a new CEO who is paid differently from the old CEO would perform differently as well.

We begin by testing whether changes in CEO pay are associated with changes in performance persistence, without conditioning on prior performance. If CEO pay and skill are connected, CEOs with similar wages should be similarly skilled and perform similarly. Greater differences in pay suggest greater differences in skill and therefore less correlation between the firm's performance under the old CEO and its performance under the new CEO. In each year $t$, we select firms that witnessed a turnover the previous year (t-1). We then relate the firm's performance in year prior to the old CEO's departure (t-2) to the firm's performance after the new CEO has had a year on the job (t).

As before, each CEO's pay is categorized into 5 categories, ranging from 1 to 5 , based on quintiles formed using industry pay levels. The difference between the two CEO's pay is the measured simply as the difference between their quintiles. We compute the absolute value of these changes, so the change in compensation varies from 0 to $4 .^{23}$ All observations with compensation change greater than 2 are lumped together to form three categories of compensation change of 0,1 , and $>2$. We then estimate the firm's performance persistence for each of these three categories.

As reported in Table 8 below, we find that firm's post-turnover performance is less similar to its pre-turnover performance if the new CEO's pay is not similar to the former CEOs pay. This is consistent with the idea that changes in pay are connected to changes in skill, but is only suggestive. Ideally we would examine this subsample in greater detail to see whether pay increases are associated with performance improvements, and how performance-based pay and environmental constraints affect pay and

\footnotetext{
${ }^{23}$ Therefore the new CEO's compensation information is from year $\mathrm{t}-1$ and the old CEOs compensation information is from date $\mathrm{t}-3$.
} 
skill. ${ }^{24}$ However, we have only around 200 observations with pay increases and pay reductions and further partitions reduce our chances of finding statistical significance. There is also a potential bias with the CEO turnover sample that makes it difficult to detect positive persistence. CEO turnovers are often associated with poor performance and there are fewer instances of CEO turnover following good performance. Thus it is difficult to observe any statistically significant positive persistence following good performance, but we have a better chance in detecting patterns among reversals of poor performance.

Nevertheless, we perform these regressions based on performance intensity, environmental constraints, persistence and reversals and unsurprisingly find that most of our estimated coefficients are statistically insignificant. ${ }^{25}$ The only significant findings exist when using only performance-based pay. See Table 9 below. We find that an increase in CEO pay is associated with a greater likelihood of reversing poor performance only when pay is highly dependent on firm performance. Surprisingly, when performance-based pay is low, an increase in CEO pay is associated with a greater likelihood of continuing poor performance. These findings confirm our earlier findings on the importance of performance-based pay in the link between pay and skill.

[Insert Table 8 and 9 about here]

These findings are also of interest because they address an alternative interpretation of our earlier results using the sample without CEO turnovers. Hayes and Schaeffer (2000) show that the portion of CEO pay that is unexplained by current performance might reflect the fact that boards observe performance that public markets will only observe in the future. That is, boards might pay CEOs today for their good performance that will yield improved results tomorrow. If higher unexplained variation in pay is also related to higher CEO pay levels, then it might be the case that high pay is correlated with future good

\footnotetext{
${ }^{24}$ Note that by considering positive persistence and reversals we are already partitioning the sample into two categories based on prior performance. Any further partitioning (e.g., on incentive pay) generates four categories he problem is exacerbated when using environmental constraints. Since the measure for environmental constraints is not available for all the firms, we also lose firms by partitioning by this attribute.

${ }^{25}$ The results, in the interests of space, are not reported.
} 
performance because boards observe and pay for CEO effort not yet reflected in public measures of performance. ${ }^{26}$ However, in a sample where there is a CEO change, there is no history for the new CEO and therefore any link between pay and skill is unlikely to be driven by realized good performance that is not yet reflected in public measures of performance. The fact that performance changes across CEOs depends on their pay changes is not likely to be due to driven by the fact that boards may pay CEOs for performance that is not yet reflected in public measures of performance. More importantly, this alternative interpretation cannot explain the negative association between pay and skill that we observe in large firms operating in high environmental constraints and no monitoring shareholders. ${ }^{27}$

Nevertheless, if boards do pay CEOs in advance of firm performance, this might produce a pattern of high pay and subsequently better performance even if firm performance varies randomly from year to year. To rule out the possibility that CEO skill is simply an artifact of this sort of process, we first examine the frequency of pay changes. If CEO skill is not constant over time, as this interpretation suggests, then CEO pay will vary a lot over time as well. We examine compensation changes from year to year (in terms of industry adjusted quintile) and find that in fact more than $80 \%$ of the time there is either no change in CEO pay or a change of 1 quintile. Thus, it appears that pay is relatively stable over time and does not change a lot from year to year as this alternative would suggest. We also re-ran our regressions using only CEOs that were consistently identified as highly-paid in consecutive years, with largely similar results.

\footnotetext{
${ }^{26}$ Note that higher unexplained variation is not always related to higher pay. For example, a CEO who gets a high pay concurrently with high firm performance has little unexplained variation in CEO pay but a CEO who gets a high pay when firm performance is poor has a high unexplained variation. Thus, the interpretation that pay reflects realized performance not yet reflected in public performance measures is more applicable for reversals, where both pay is high and unexplained variation is high too. Encouragingly, it is exactly here too that the turnover results suggest that pay and skill are related.

${ }^{27}$ It is also useful to address a concern that Hayes and Schaefer (2000) acknowledge in the interpretation of their results. They discuss the possibility that the link between higher unexplained compensation and high future performance might be due to earnings manipulation by the CEO. If managers indeed smooth earnings between time periods and are paid for the 'true' current earnings, it should be difficult to detect reversals because managers would "borrow" from future good times to boost current bad times. Thus, smoothing would mask rather than explain any reversals.
} 


\section{PART VI. THE IMPACT OF A GOOD CEO}

Using patterns of firm performance as our measure of CEO skill, we have shown that highly paid CEOs are more skilled when firms are small, have an external monitor, or operate with few environmental constraints. We now attempt to estimate the economic impact of a good CEO, first by estimating the long run returns for a portfolio of firms run by good CEOs in industries where pay and skill are linked. We also make rough estimates of the impact of a skilled CEO using ROA as our measure of performance.

\section{A. Abnormal returns}

We apply several screens to detect the "good" CEOs. In each year, we select firms that are small (below median size of 1.2 billion dollars), face few environmental constraints and have an institutional blockholder. From our earlier results, we know that CEO pay is related to CEO skill in these firms. Therefore, we next identify the highly paid (highly skilled) CEOs in these firms as those whose pay falls in quintiles 4 or 5 based on industry pay distribution. Since performance-based pay also strengthens the link between pay and skill, among these CEOs we also examine those where pay is more dependent on firm performance, which we define as greater than industry median level of performance-based pay. Both these compensation characteristics are measured in year before we measure their performance.

After using these screens, we are left with 341 firm years, 187 unique firms and an average of 38 stocks per month. At the beginning of each year we use this list of good CEOs to create equally weighted and value-weighted portfolios of these CEOs/firms. Each selected CEO/firm is held to the end of the year, and a new portfolio is formed at the beginning of the next year based on the new list of "good" CEOs. Returns to this portfolio series is computed using monthly observations, giving us 96 observations from 1994 to 2001 . We then analyze the equity returns for a portfolio that consists of these "good" CEOs.

To ensure that differences in risk or style do not drive our results, we calculate abnormal returns using the four-factor model (Fama and French, 1993) augmented by the momentum factor (see Jegadeesh 
and Titman, 1993) and Carhart (1997). The estimated abnormal return is the constant or alpha in the model:

$$
\mathrm{R}_{\mathrm{t}}=\alpha_{\mathrm{t}}+\mathrm{bMkT}_{\mathrm{t}}+\mathrm{cSMB}_{\mathrm{t}}+\mathrm{dHML}_{\mathrm{t}}+\mathrm{eUMD}_{\mathrm{t}}+\varepsilon_{\mathrm{t}}
$$

where $R_{t}$ is the excess return over the riskless rate to the good CEO portfolio in month $t . M_{t}, S M B_{t}$, $\mathrm{HML}_{\mathrm{t}}$ and $\mathrm{UMD}_{\mathrm{t}}$ are the returns on the market portfolio and the three portfolios that capture the size, bookto-market and momentum effects.

We find that the portfolio of "good" CEOs earns an annualized abnormal return of $11.76 \%(6.6 \%)$ for the equally weighted (value-weighted) portfolio. See Panel A of Table 10 below. $^{28}$ The abnormal returns for the equal-weighted portfolio are significant at the $1 \%$ level with t-statistics of 3.22 (the t-statistic for the value-weighted portfolio is 1.53). ${ }^{29}$ However, it is difficult to interpret these results as the returns to managerial skill if all small firms with few environmental constraints and blockholders share a systematic factor which the asset-pricing model does not correct for. ${ }^{30}$

To isolate the returns attributable specifically to differences in CEO pay, we next construct a portfolio that buys firms managed by highly-paid CEOs and sells firms managed by low-pay CEOs in conditions (a) where we expect pay and skill to be matched and (b) where we expect no link between pay and skill. In this way, common factors affecting firm returns should wash out, and we should better identify returns associated with differences in skill. As reported in Panel B of Table 10, this portfolio of high pay CEOs minus low pay CEOs generates a mean annual return of $3.7 \%$ in industries where pay and skill are linked, but $-4.0 \%$ in industries in which there is not a link. While the mean returns are statistically insignificant, the equally weighted portfolio of high pay CEOs minus low pay CEOs earned statistically

\footnotetext{
${ }^{28} \mathrm{We}$ focus on equally weighted portfolio as we find CEOs pay and skill to be linked in smaller firms. While we have chosen small firm based on a size screen using asset values (consistent with our earlier results), they might include some big firms with few assets. Thus market capitalization might have further information on firm size.

${ }^{29}$ Since Cremers and Nair (2004) show that firms with both blockholders and low takeover defense have high abnormal returns we check to see the distribution of takeover defense measures in the "good CEO" firms to see whether this is driving our results. We find that there is sufficient variation in the governance of these firms that it is unlikely that the alphas are driven by this effect. In our sample, the mean value of the governance index constructed by Gompers, Ishii and Metrick (2003) is 8.11 and the standard deviation is 2.38 with the minimum value being 3 and the maximum being 14 .

${ }^{30}$ We find in unreported regressions that an equally weighted portfolio of small firms with a blockholder in industries with few environmental constraints earn abnormal returns regardless of CEO characteristics.
} 
significant (at the 10\% level) abnormal annual returns of $8.3 \%$ when pay and skill are linked and statistically insignificant returns of $1.3 \%$ when pay and skill are not linked. The magnitude of this is economically significant. Consistent with our findings that the link between pay and skill is observed more in smaller firms, we find no such abnormal returns for the value-weighted portfolios. Thus, we find that a portfolio that buys high pay CEOs and sells low pay CEOs earns abnormal returns conditional on the firms operating in conditions where pay and skill are likely to be linked.

[Insert Table 10 about here]

\section{B. ACCOUNTING PERFormanCE}

We now characterize the impact of a highly paid CEO on firm performance using accounting measures, partitioned by firm size and environmental constraints (we obtain similar estimates when we instead partition by the dispersion of analyst forecasts). As reviewed in Part III, if current firm performance is poor, a highly paid CEO in a small firm with few environmental constraints is more likely to reverse this poor performance than his lower paid counterpart. The difference between the likelihood of reversals between the high paid and the low paid CEOs is 0.16 (see Table 3, small firms facing low constraints). For an average firm in this category (median firm size $=457 \mathrm{~m}$ ), the increase in ROA on moving from poor performance to good performance is $4.93 \%$. Thus the increase in earnings associated with a highly paid CEO is $\$ 3.5$ million $(0.16 \times 4.93 \% \times 457 \mathrm{~m})$. Similarly, for a large firm with few environmental constraints the likelihood of reversals is higher under the highly paid CEO than under the low paid CEO by 0.5 . For an average firm in this category (median firm size is roughly $\$ 5$ million with an average increase in $\mathrm{ROA}=2.85 \%$ ), this translates into expected incremental earnings of $\$ 72$ million.

For a large firm operating with high environmental constraints, the highly paid CEO is more, and not less, likely to continue poor performance. Highly paid CEOs of these firms were earlier classified as 'bad'. The losses associated with such CEOs can be computed similarly. For an average large firm with 
high environmental constraints (median firm size is $3,650 \mathrm{~m}$ with an average increase in $\mathrm{ROA}=4.93$ ), a highly paid CEO in these firm is associated with a loss of $0.21 \times 4.93 \%$ x $3650=37.78$ million. The magnitude of these numbers appears to be larger than the amount of pay itself, suggesting that the level of executive compensation may provide information about the firm's governance and performance generally.

\section{PART VII. CONCLUSION}

Our analysis has two important conclusions, one methodological and one substantive. We have introduced a new measure of CEO skill that allows us to assess the relation of CEO skill and pay. We assess skill in terms of the CEO's role in perpetuating good firm performance and in reversing poor firm performance. Substantively, we provide evidence that, in small firms, highly paid CEOs are likely to be skilled, particularly when the CEO receives performance-based pay and when a large shareholder monitors CEO performance. Higher pay is also associated with higher skill when CEOs face fewer environmental constraints on managerial discretion. Conversely, when managerial discretion is constrained by environmental factors and the firm is large or when no large shareholder monitors CEO performance, highly paid CEOs perform badly. These effects are both statistically significant and economically important. We estimate that, when pay and skill are positively linked, highly paid -- i.e., good -- CEOs earn abnormal annual returns of more than $8 \%$ relative to poorly paid CEOs. Moreover, the mean return of firms in which pay and CEO performance are linked exceeds the mean return of firms in which pay and CEO performance are not linked by almost $8 \%$.

These findings shed light on a highly debated question - 'are CEOs overpaid?" The answer appears to support both sides on the debate. On the one hand, we find a set of firms in which highly paid CEOs perform better (i.e. small firms where the CEO receives performance-based pay or where a large shareholder monitors CEO performance, and firms with few environmental constraints on managerial discretion). In these firms, highly paid CEOs are actually on average good- they consistently do better than their peers. We conclude that compensation problems in such firms are likely outliers ("a few bad apples") 
rather than signs of a systematic problem. On the other hand, we also find a set of firms in which highly paid CEOs are likely overpaid on average (firms facing environmental constraints that are either large or that lack a large shareholder to monitor CEO performance). Appendix A provides additional detail about highly paid CEOs in such firms where pay and skill are negatively related. In these firms highly paid CEOs perform actually worse on average and so there is no justification for their higher pay. Compensation problems here may be more widespread and therefore suggestions for reform may be more profitably directed at these firms.

Finally, these results suggest that executive compensation can be a window to understanding firm performance and governance generally. Executive compensation data predicts firms that will generate significant abnormal returns and that will be associated with large accounting losses. The magnitude of these numbers appears to be larger than the amount of pay itself, suggesting that the level of executive compensation may provide information about the firm's governance and performance generally. 


\section{REFERENCES}

Adams, Renee, Heitor Almeida and Daniel Ferreira, (2004) "Powerful CEOs and Their Impact on Corporate Performance", forthcoming, Review of Financial Studies.

Baker, George P., Michael C. Jensen, and Kevin J. Murphy (1988) "Compensation and Incentives: Practice vs. Theory." Journal of Finance 63:3, pp. 593-616.

Bebchuk, Lucian Arye and Jesse M. Fried. 2004. Pay without Performance, MIT Press.

Bebchuk, Lucian Arye, Jesse M. Fried, and David I. Walker. 2002. "Managerial Power and Rent Extraction in the Design of Executive Compensation." University of Chicago Law Review 69:3, pp. 751846.

Bertrand, Marianne and Antoinette Schoar, (2003), "Managing with Style: The Effect of Managers on Firm Policies", The Quarterly Journal of Economics 118,4.

Bertrand, Marianne and Sendhil Mullainathan. 2001. “Are CEO's Rewarded for Luck? The Ones Without Principals Are.” Quarterly Journal of Economics, pp. 901-932.

Brown, Stephen and William Goetzman (1995), "Performance Persistence”, Journal of Finance, 50

Carhart, Mark (1997), “On persistence in mutual fund performance”, Journal of Finance, 52.

Core, John E., Wayne Guay, and David F. Larcker. 2001. "Executive Equity Compensation and Incentives: A Survey," Working Paper, Wharton School.

Cremers, K.J.M. and V.B. Nair, (2004), "Governance Mechanisms and Equity Prices", Journal of Finance, forthcoming.

Fama, E. F., and K. R. French (1997), "Industry Costs of Equity," Journal of Financial Economics, 93, 153- 194

Finkelstein, Sydney and Donald. C. Hambrick, Strategic Leadership: Top executives and their effects on organizations. West, 1996.

Gompers, P.A., J.L. Ishii, and A. Metrick (2003), “Corporate governance and equity prices,” The Quarterly Journal of Economics, Vol. 118

Hayes, Rachel M. and Scott Schaefer (2000), "Implicit contracts and the explanatory power of top executive compensation for future performance.” RAND Journal of Economics 31, pp.273-293.

Hallock, Kevin F. and Paul Oyer (1999), The timeliness of performance information in determining executive compensation, Journal of Corporate Finance 5, 303.

Hambrick, Donald C. and E. Abrahamson (1995), "Assessing the amount of managerial discretion in different industries." Academy of Management Journal, October. 
Hambrick, Donald C. and Sydney Finkelstein (1987), "Managerial Discretion: A bridge between polar views of organizational outcomes" in Research in Organizational Behavior, B. Straw and LL Cummings (eds), JAI Press.

Hannan, Michael and John Freeman (1977), "The Population Ecology of Organizations" American Journal of Sociology.

Himmelberg, Charles and R. Glen Hubbard (2000), Incentive Pay and the Market for CEOs: An Analysis of Pay-for-Performance Sensitivity." Working Paper.

Holmstrom, Bengt and Steven Kaplan (2003), "The State of U.S. Corporate Governance: What's right and what's wrong?" ECGI Working Paper.

Huson, M., Parrino, R., and Starks, L., 2001, "Internal Monitoring Mechanisms and CEO Turnover: A Long Term Perspective." Journal of Finance 56, 2265-2297.

Jensen, Michael and Kevin Murphy 1990, Performance Pay and top management incentives, Journal of Political Economy 98 225-64.

John, Kose and Lemma Senbet (2003), “Executive Compensation: Issues and Reform Proposals.” Working paper.

Jegadeesh, Narasimhan and Sheridan Titman (2001), “Momentum”, Journal of Finance.

Johnson, Timothy C. (2004), "Forecast Dispersion and the Cross Section of Expected Returns", The Journal of Finance 59 (5), 1957-1978.

Malmendier, Ulrike and Geoffrey Tate (2004), "Superstar CEOs”, Working paper.

Murphy, Kevin J., (2002), Explaining Executive Compensation: Managerial Power versus the perceived cost of stock options, 69 University of Chicago Law Review 847.

Murphy, Kevin J. and Jan Zobonjik, CEO Pay and Appointments: A market based explanation for recent trends," American Economic Review 94.

Murphy, Kevin J. 1999. “Executive Compensation.” in Handbook of Labor Economics. Orley Ashenfelter and David Card, eds. North Holland, pp. 2485-2563.

Murphy, Kevin J. 2002. "Explaining Executive Compensation: Managerial Power vs. the Perceived Cost of Stock Options.” University of Chicago Law Review 69, pp. 847-869.

Oyer, Paul 2004, "Why do firms use incentives that have no incentive effects?" Journal of Finance, 59, 1619. 
TABLE 1

Descriptive Statistics

This table reports descriptive statistics of a sample of 2,280 firms (10,0043 firm years) between 1992-2001. Blockholder is a dummy variable indicating whether there is a shareholder holding at least 5\% of the firm's stock. The variable measuring environmental constraint is taken from Finkelstein and Hambrick (1996). The sample includes all firms for which executive compensation, accounting and stock price data is available on Execucomp, Compustat and CRSP. Panel A gives summary statistics and Panel B lists correlation coefficients, significant at $5 \%(* *)$ and $1 \%(* * *)$ levels.

\section{$\underline{\text { Panel } A}$}

Mean

Stand. Dev.

Min

Max

$\mathrm{N}$

\section{Panel B}

Performance-based

pay

Environmental

Constraints

Assets

Block

PERFORMANCE-BA
PAY
0.46
0.28
0
1.00
9,988

$0.23 * * *$

$0.03 * *$

$0.02 * * *$

$-0.02 * *$
4,386

17,951

$1,306,260$

10,007

$$
\frac{\text { PAY }}{(1,000)}
$$

$0.10^{* * *}$

$0.11 * * *$

$0.04 * *$
$-0.15 * * *$

$0.13 * * *$ $\frac{\text { ASSETS }}{(1,000,000)} \quad \underline{\text { BLOCK }}$

$8,378 \quad 0.75$

$35,029 \quad 0.42$

$3.43 \quad 0$

$1,051,450 \quad 1.00$

$10,023 \quad 7,979$

1.00

7,112 
FIGURE 1

CEO pay by industry
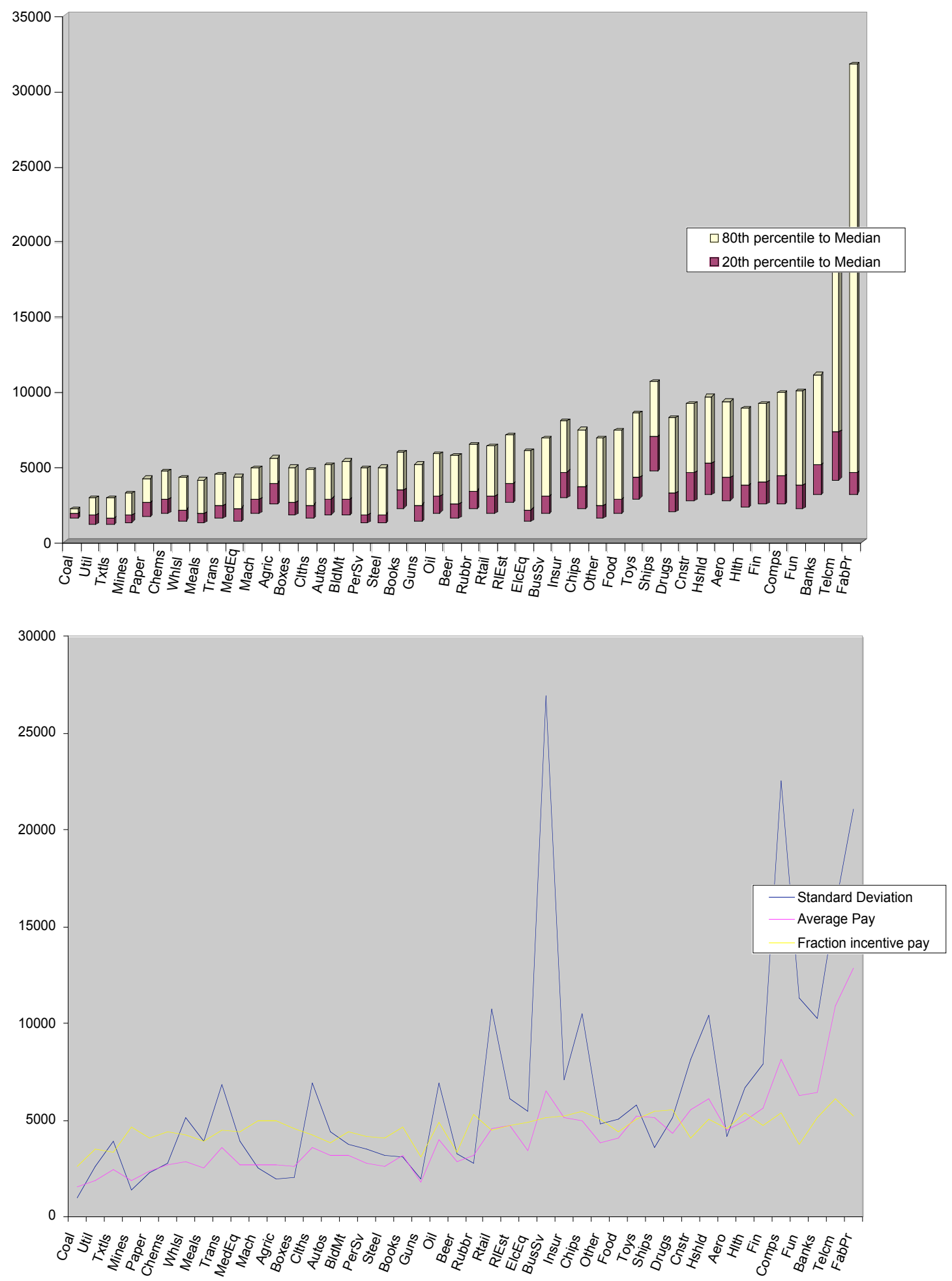


\section{Table 2}

\section{CEO PAY AND SKILL}

This table reports regression estimates of the performance of public firms between 1990 and 2001. The dependent variable is the firm's industry-adjusted accounting performance and abnormal returns. Independent variables include a dummy for a highly paid CEOs (defined as those in top 2 quintiles of industry adjusted pay in the prior year) that estimates the effect of highly paid CEOs relative to poorly paid CEOs (defined as those in bottom two quintiles). Other variables control for the prior year's performance and an interaction term. The sample includes all firms for which executive compensation, accounting and stock price data is available on Execucomp, Compustat and CRSP. Standard errors are in parentheses and are adjusted for clustering. Estimated coefficients are significant at $1(* * *), 5(* *)$, and $10\left(^{*}\right)$ percent.

Prior good performance for highly paid CEOs

Prior bad performance for highly paid CEOs

Highly paid CEO dummy

Prior good performance

Prior bad performance

R-squared

$\mathrm{N}$

\section{All firms}

Abnormal

return (quintiles)

$0.09 *$

$(0.05)$

$-0.03$

$(0.04)$

$-0.21 * * *$

$(0.05)$

$0.08 * * *$

$(0.03)$

$0.14 * * *$

$(0.03)$

.02

\section{Small firms \\ ms}

Abnormal

return

(quintiles)

\section{$\underline{\text { ROA }}$}

$0.20 * * *$

(0.03)

0.04

$(0.03)$

$-0.64 * * *$

$(0.26)$

$0.69^{* * *}$

(0.02)

$0.39 * * *$

(0.02)

.31
$0.17 * *$

$(0.09)$

$-0.35 * * *$

(0.07)

$-0.43^{* * *}$

(0.08)

0.04

(0.05)

$0.13^{* * *}$

(0.04)

0.01

2,985 $\underline{\text { ROA } \quad \begin{array}{c}\text { Abnormal } \\ \text { return } \\ \text { (quintiles) }\end{array}}$

$0.11^{*}$

(0.07)

$-0.17 * *$

(0.07)

$-0.33^{*}$

(0.28)

$0.74 * * *$

(0.03)

$0.41 * * *$

(0.03)

0.33

2,670
Big Firms

\begin{tabular}{cl}
\hline & \\
$\begin{array}{c}\text { Abnormal } \\
\text { return } \\
\text { (quintiles) }\end{array}$ & ROA \\
\cline { 2 - 2 } 0.06 & -0.01 \\
$(0.09)$ & $(0.09)$ \\
0.03 & -0.18 \\
$(0.04)$ & $(0.13)$ \\
0.00 & -0.12 \\
$(0.08)$ & $(0.46)$ \\
0.11 & $0.94 * * *$ \\
$(0.09)$ & $(0.09)$ \\
$0.22 * * *$ & $0.56 * * *$ \\
$(0.06)$ & $(0.13)$ \\
0.05 & 0.38 \\
2,942 & 2,540
\end{tabular}


TABLE 3

ENVIRONMENTAL CONSTRAINTS, CEO PAY AND SKILL

This table reports regression estimates of firm industry-adjusted accounting performance and abnormal returns, after partitioning firms based on the regulatory and environmental constraints placed on managerial discretion. Independent variables include a dummy for a highly paid CEOs (defined as those in top $40 \%$ of industry adjusted pay) in the prior year and estimates the effect of highly paid CEOs relative to poorly paid CEOs (defined as those in bottom two quintiles). Other variables control for the, as well as they prior year's performance and an interaction term. The sample includes all firms for which executive compensation, accounting and stock price data is available on Execucomp, Compustat and CRSP. Standard errors are in parentheses. Estimated coefficients are significant at $1(* * *), 5(* *)$, and $10\left(^{*}\right)$ percent.

Prior good performance for highly paid CEOs

Prior bad performance for highly paid CEOs

CEO Pay

Prior good performance

Prior bad performance

R-square

\section{$\underline{\text { Low Environmental Constraints }}$}

Abnormal

return

Quintiles

$0.24 * * *$

$(0.08)$

$-0.17 * *$

$(0.07)$

$-0.23 * * *$

$(0.08)$

0.03

$(0.05)$

0.03

$(0.05)$

0.01 $\underline{\text { High Environmental Constraints }}$

Abnormal

return

Quintiles

$-0.14$

$(0.10)$

$-0.06$

$(0.07)$

$-0.22 * * *$

(0.08)

$0.15^{* * *}$

(0.06)

0.20 ***

(0.05)

0.03
$\underline{\mathrm{ROA}}$

$0.16^{* * *}$

(0.07)

0.09

(0.08)

$-0.12$

$(0.23)$

(0.03)

$0.35 * * *$

(0.03)

.19
$0.43 * * *$ 
FIGURE 2

CEO PAY AND THE PERFORMANCE PERSISTENCE OF HIGHLY PAID CEOS
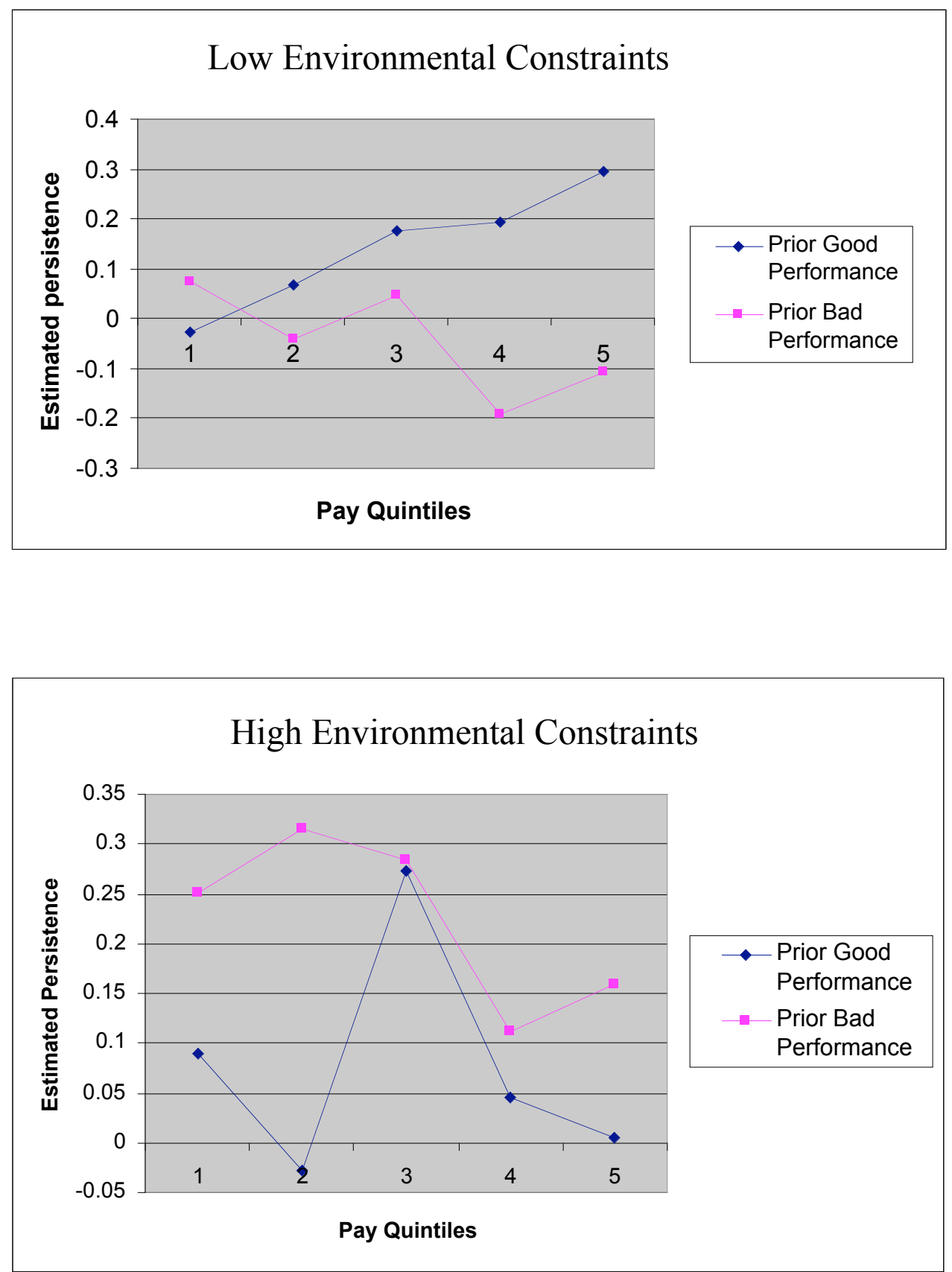
TABLE 4

MANAGERIAL SKILL BY FIRM SIZE AND ENVIRONMENTAL CONSTRAINT

We report the marginal impact of a highly paid CEO on firm performance. Firms are first partitioned into big (above median) and small (below median) firms, and then further partitions firms by the severity of environmental constraints on managerial discretion The table reports results from a regression estimating the firm's industry-adjusted accounting performance and abnormal returns. We report only the estimated coefficients for firms lead by highly paid CEOs conditional on positive prior performance (above industry median) and prior bad (below industry median) performance (or "reversals"), that estimates the effect of highly paid CEOs relative to poorly paid CEOs. The regression model includes other unreported independent variables, including a constant, a dummy for highly paid CEOs, and controls for prior year performance. The sample includes all firms for which executive compensation, accounting and stock price data is available on Execucomp, Compustat and CRSP. Estimated coefficients are significant at $1(* * *)$, $5(* *)$, and $10(*)$ percent.

\section{Low constraints}

Prior good performance

Prior bad performance

High constraints

Prior good performance

Prior bad performance

\begin{tabular}{cccc}
\hline \multicolumn{1}{c}{ Big firms } & & \multicolumn{2}{c}{ Small Firms } \\
$\begin{array}{c}\text { Abnormal } \\
\text { Returns } \\
\text { (quintiles) }\end{array}$ & $\underline{\text { ROA }}$ & $\begin{array}{c}\text { Abnormal } \\
\text { Returns } \\
\text { (quintiles) }\end{array}$ & $\underline{\text { ROA }}$ \\
-0.2 & 0.00 & $0.18^{*}$ & -0.08 \\
0.0 & $-0.50^{*}$ & $-0.27^{* *}$ & $-0.17^{*}$ \\
0.12 & $-0.38^{* * *}$ & 0 & $0.41^{* *}$ \\
0.06 & $0.21^{* *}$ & $-0.28^{*}$ & -0.01
\end{tabular}




\section{TABLE 5}

\section{ROBUSTNESS: IMPORTANCE OF FIRM SPECIFIC FACTORS, CEO PAY AND SKILL}

Firms are portioned based on the importance of firm specific factors, as measured by the within industry dispersion in analysts forecasts (see description in Part 5). This table reports regression estimates of firm industry-adjusted accounting performance and abnormal returns. Independent variables include a dummy for a highly paid CEOs (defined as those in top $40 \%$ of industry adjusted pay) in the prior year, as well as the prior year's performance and an interaction term. The sample includes all firms for which executive compensation, accounting and stock price data is available on Execucomp, Compustat and CRSP. Standard errors are in parentheses. Estimated coefficients are significant at $1(* * *), 5(* *)$, and $10\left(^{*}\right)$ percent.

Prior good performance

for highly paid CEOs

Prior bad performance for highly paid CEOs

\section{CEO Pay}

Prior good performance

Prior bad performance

R-square
Low Importance

Abnormal

return

Quintiles

0.02

$(0.09)$

0.05

$(0.05)$

$-0.20 * * *$

(0.06)

$0.09 *$

$(0.05)$

$0.24 * * *$

$(0.04)$

0.01 $\underline{\text { High Importance }}$

Abnormal

return

Quintiles

$0.12 *$

(0.07)

$\underline{\mathrm{ROA}}$

$\frac{\mathrm{ROA}}{0.29 * * *}$

(0.05)

$-0.11^{*}$

(0.06)

(0.06)

$-0.82 * *$

$(0.29)$

$0.57 * * *$

$-0.19 * *$

$(0.08)$

$0.09 * *$

$(0.05)$

0.06

(0.04)

0.03
$0.17 * * *$

(0.04)

$-0.16^{* *}$

(0.07)

$-0.61$

$(0.42)$

$0.74 * * *$

(0.03)

$0.40 * * *$

(0.02) 
TABLE 6

Performance-BASEd PAY AND CEO SKILl

We report the marginal impact of a highly paid CEO on firm performance. Panel A reports results for all firms. Panel B partitions firms by size, dividing the sample into two subgroups, big (above median) and small (below median) firms. Panel $\mathrm{C}$ partitions firms by the existence of a monitoring shareholder (defined as an institutional shareholder holding at least a 5\% block of shares.) The table reports results from a regression estimating the firm's industry-adjusted accounting performance and abnormal returns. We report only the estimated coefficients for firms lead by highly paid CEOs, conditional on positive prior performance (above industry median) and prior bad (below industry median) performance (or "reversals"). The regression model includes other unreported independent variables, including a constant, a dummy for highly paid CEOs, and controls for prior year performance. The sample includes all firms for which executive compensation, accounting and stock price data is available on Execucomp, Compustat and CRSP. Estimated coefficients are significant at $1(* * *), 5(* *)$, and $10(*)$ percent.

$\underline{\text { Panel A }}$

All firms

Prior good

performance

Prior bad performance

$\mathrm{N}$

Panel B

Big Firms

Prior good

performance

Prior bad performance

Small Firms

Prior good

performance

Prior bad performance

\section{Panel C}

No blockholder

Prior good

performance

Prior bad performance

Blockholder

Prior good

performance

Prior bad performance

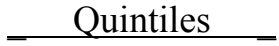

Low performance-

based pay
High performance-

based pay
ROA

Low performance-

based pay
High performancebased pay
$0.21^{*}$

0.01

2,869

0.18

0.08

0.23

$-0.46^{* * *}$

0.23

0.02

0.16

$-0.04$
0.17

$-0.09$

2,937

0.09

$-0.10$

$0.24 *$

$-0.37 * * *$
0.07

0.06

2,471

$-0.03$

$-0.13$

0.12

$-0.20$
0.06

$-0.37$

$0.51^{* * *}$

$-0.54 * * *$

$-0.37$
$0.58 * * *$

$-0.62 * * *$

2,628 


\section{TABLE 7 \\ CEO SKILl, ENVIronmental DisCReTION AND BLOCKHOLDERS}

We report the marginal impact of a highly paid CEO on firm performance. Firms are first partitioned by the existence of a monitoring shareholder (defined as an institutional shareholder holding at least a 5\% block of shares.) Panel A then further partitions firms by the severity of environmental constraints on managerial discretion. Panel B partitions firms by firm size. The table reports results from a regression estimating the firm's industry-adjusted accounting performance. We report only the estimated coefficients for firms lead by highly paid CEOs conditional on positive prior performance (above industry median) and prior bad (below industry median) performance (or "reversals"). The regression model includes other unreported independent variables, including a constant, a dummy for highly paid CEOs, and controls for prior year performance. The sample includes all firms for which executive compensation, accounting and stock price data is available on Execucomp, Compustat and CRSP. Estimated coefficients are significant at $1(* *), 5(* *)$, and $10(*)$ percent.

$\underline{\text { Panel A }}$

Low environmental constraints Prior good performance Prior bad performance

High environmental constraints Prior good performance

Prior bad performance

Panel B

Small firms

Prior good performance

Prior bad performance

Big firms

Prior good performance

Prior bad performance

\begin{tabular}{ccc} 
No blockholder & & Blockholder \\
\hline-0.12 & & 0.01 \\
$-0.36^{* *}$ & & $-0.40^{* * *}$ \\
& & \\
$-0.21^{*}$ & & $0.21^{* *}$ \\
$0.35^{* * *}$ & & -0.12 \\
& \\
& \\
-0.33 & 0.08 \\
-0.27 & $-0.31^{* * *}$ \\
& \\
0.04 & 0.03 \\
0.12 & $-0.28^{*}$
\end{tabular}




\section{TABLE 8}

\section{CEO PAY, SKILL AND TURNOVER}

This table examines firm performance in a two year window surrounding CEO turnover and reports the correlation between performance under one $\mathrm{CEO}$ and the performance under the successor. Panel A reports the overall performance persistence, conditional on the change in pay between the old CEO and the new CEO, for firm ROA and abnormal return quintiles. Panel B breaks these numbers down to reflect performance persistence for those changes associated with pay increases and those associated with pay decreases. The sample includes all firms for which executive compensation, accounting and stock price data is available on Execucomp, Compustat and CRSP. T-statistics are in parentheses.

No pay change $\quad \underline{1 \text { quintile pay change } \quad 2 \text { quintile pay change }}$

Panel A:

Abnormal returns

ROA

Abnormal returns

ROA

$\mathrm{N}$
0.18

(2.91)

0.58

(9.95)

1 quintile pay change

$\begin{array}{cccc}\begin{array}{c}\text { Pay } \\ \text { decrease }\end{array} & \begin{array}{c}\text { Pay } \\ \text { increase }\end{array} & \begin{array}{c}\text { Pay } \\ \text { decrease }\end{array} & \begin{array}{c}\text { Pay } \\ \text { increase }\end{array} \\ 0.10 & 0.18 & 0.01 & 0.10 \\ (1.14) & (2.11) & (0.05) & (0.8) \\ 0.31 & 0.46 & 0.41 & 0.32 \\ (5.38) & (9.80) & (2.08) & (4.46)\end{array}$

135

0.15

(2.36)

0.41

(11.03)

0.06

$(0.65)$

0.35

(4.41)

2 quintile pay change

307
145

66

113 
TABLE 9

\section{CEO PAY, SKILL AND TURNOVER}

This table examines firm performance in a two year window surrounding CEO turnover and reports the correlation between performance under one CEO and the performance under the successor. Panel A reports the overall performance persistence, conditional on the change in pay between the old CEO and the new CEO. Panel B breaks these numbers down to reflect performance persistence for those changes associated with pay increases and those associated with pay decreases. The sample includes all firms for which executive compensation, accounting and stock price data is available on Execucomp, Compustat and CRSP. The t-statistics are in parentheses.

\section{HIGH INCENTIVE COMPONENT}

$\begin{array}{lc} & \begin{array}{c}\text { Abnormal } \\ \text { return } \\ \text { Quintiles }\end{array} \\ \text { Prior good performance } * & 0.11 \\ \text { increase in CEO pay } & (0.69) \\ \text { Prior bad performance } * & -0.04 \\ \text { increase in CEO pay } & (0.31) \\ \text { Prior good performance } & 0.00 \\ & (0.01) \\ \text { Prior bad performance } & 0.11 \\ \text { R-square } & (1.47) \\ & 0.02\end{array}$

\section{LOW INCENTIVE COMPONENT}

Abnormal

return

$\underline{\mathrm{ROA}}$

$-0.02$

$(-0.19)$

Quintiles

$-0.03$

ROA

(0.13)

(1.60)

$-0.35 * * *$

$(-3.38)$

0.14

(0.54)

$0.74 *$

(1.86)

$0.55^{* * *}$

(8.23)

$0.64 * * *$

(8.38)

.30
0.06

(0.63)

0.15

(1.96)

0.01
$0.67 * * *$

(9.16)

$0.11^{* * *}$

(2.36) 


\section{TABLE 10}

\section{AbNORMAL RETURNS FOR GOOD CEOS}

This table presents the abnormal returns (alphas) to a value-weighted portfolio of highly paid CEOs in firms where pay and skill are related (See text for conditions where pay and skill are related). The alphas are computed relative to a Fama-French (1993) four factor model that includes the market, size, book to market and momentum factors. We identify good CEOs at the beginning of the year and hold the portfolios for either one or two years. All abnormal returns are annualized and presented with the respective tstatistics in parentheses.

\section{Mean return Abnormal return}

\section{Panel A: CEO Pay in top 40\%}

Where pay and skill are linked

Where pay and skill are NOT linked

$13.44 \%$

$(1.51)$

$3.00 \%$

$(0.12)$

Panel B: High Pay CEOs - Low Pay CEOS

Where pay and skill are linked

Where pay and skill are NOT linked
$3.72 \%$

$(0.21)$

$-3.96 \%$

$(0.17)$
$11.76 \% * * *$

$(3.22)$

$-2.00 \%$

$(0.79)$

$8.28 \% *$

$(1.71)$

$1.32 \%$

$(0.18)$ 


\section{Appendix A \\ Performance and Compensation Details for Highly Paid CEOs \\ in Firms with High Environmental Constraints and No Blockholders}

This table reports compensation and performance data from a set of firms in which CEO pay is negatively related to skill. We first identify firms that operate in environments characterized by high constraint on managerial discretion and that have no blockholders. We then report detailed information on the worst performers in this group of firms - that is, CEOs that (1) appear at least 3 times in our sample; (2) and under whom firm performance declined at least $50 \%$ of the time. In Panel A, the remaining CEOs are then ranked by the fraction of years in decline. Panel B ranks them by the amount by which their salary exceeds their industry compensation (on average) and Panel $\mathrm{C}$ by the sum of the firm's decline in ROA under their control. Executive compensation data is from Execucomp and firm data is from Compustat and CRSP.

\begin{tabular}{|c|c|c|c|c|c|c|c|c|c|}
\hline Firm & CEO & $\begin{array}{l}\text { Years } \\
\text { in } \\
\text { Sample }\end{array}$ & $\begin{array}{c}\text { Years } \\
\text { Industry } \\
\text { Adjusted } \\
\text { ROA } \\
\text { Declined }\end{array}$ & $\begin{array}{c}\% \\
\text { declined }\end{array}$ & $\begin{array}{l}\text { Average } \\
\text { Change } \\
\text { in ROA }\end{array}$ & $\begin{array}{c}\text { Industry } \\
\text { Adjusted } \\
\text { ROA } \\
\text { declines }\end{array}$ & $\begin{array}{c}\text { Average } \\
\text { Difference } \\
\text { between Pay } \\
\text { and } \\
\text { Performance } \\
\text { Quintiles }\end{array}$ & \multicolumn{2}{|c|}{$\begin{array}{c}\text { Average } \\
\text { Industry } \\
\text { Adjusted } \\
\text { Compensation }\end{array}$} \\
\hline CENTERPO & Don Jordan & 4 & 4 & $100 \%$ & -0.72 & -2.88 & 2.50 & $\$$ & 5,022 \\
\hline DOMINION & Thos. Capps & 5 & 4 & $80 \%$ & 0.00 & -0.80 & 1.80 & $\$$ & 2,808 \\
\hline AT\&T COR & Robert Allen & 4 & 3 & $75 \%$ & 0.11 & -7.74 & 2.00 & $\$$ & 6,833 \\
\hline VERIZON & Raymond Smith & 4 & 3 & $75 \%$ & -0.24 & -2.76 & 2.25 & $\$$ & 5,286 \\
\hline SONOCO & Charles Coker & 4 & 3 & $75 \%$ & -0.90 & -4.17 & 1.25 & $\$$ & 1,705 \\
\hline AT\&T CORP & C. Armstrong & 3 & 2 & $67 \%$ & -1.53 & -4.77 & 1.33 & $\$$ & 13,470 \\
\hline UNITED TECH & George David & 3 & 2 & $67 \%$ & 0.05 & -1.09 & 2.67 & $\$$ & 5,057 \\
\hline UNION PA & Drew Lewis & 3 & 2 & $67 \%$ & -0.49 & -2.17 & 2.67 & $\$$ & 4,916 \\
\hline AVERY DEN. & Charles Miller & 3 & 2 & $67 \%$ & 0.09 & -1.33 & 1.33 & $\$$ & 2,407 \\
\hline DUKE ENE & Richard Priory & 3 & 2 & $67 \%$ & -0.49 & -2.07 & 1.67 & $\$$ & 1,939 \\
\hline TXU CORP & Erle Nye & 6 & 4 & $67 \%$ & -0.03 & -5.09 & 1.83 & $\$$ & 927 \\
\hline KIMBERLY & Wayne Sanders & 8 & 5 & $63 \%$ & 0.24 & -11.08 & 1.63 & $\$$ & 5,606 \\
\hline EDISON I & John Bryson & 5 & 3 & $60 \%$ & 0.04 & -0.25 & 2.60 & $\$$ & 1,208 \\
\hline PACIFICORP & Fred Buckman & 5 & 3 & $60 \%$ & -0.35 & -2.03 & 2.20 & $\$$ & 1,016 \\
\hline AQUILA I & Richard Green J & 7 & 4 & $57 \%$ & -0.22 & -2.45 & 2.57 & $\$$ & 3,138 \\
\hline DISNEY & Michael Eisner & 6 & 3 & $50 \%$ & -0.10 & -5.28 & 0.50 & $\$$ & 38,109 \\
\hline EXXON & Lee Raymond & 8 & 4 & $50 \%$ & -0.06 & -5.74 & 1.75 & $\$$ & 19,786 \\
\hline GANNETT & John Curley & 6 & 3 & $50 \%$ & 0.11 & -6.85 & 2.67 & $\$$ & 3,100 \\
\hline FPL GROU & James Broadhead & 6 & 3 & $50 \%$ & 0.04 & -0.56 & 2.33 & $\$$ & 3,069 \\
\hline NATIONAL & Bernard Kennedy & 6 & 3 & $50 \%$ & 0.04 & -2.93 & 2.50 & $\$$ & 2,385 \\
\hline SOUTHERN & A. Dahlber & 4 & 2 & $50 \%$ & -0.07 & -0.63 & 2.25 & $\$$ & 871 \\
\hline CONSOLID & George Davidson & 4 & 2 & $50 \%$ & 0.24 & -1.51 & 1.75 & $\$$ & 744 \\
\hline PUBLIC SER & E. Ferland & 4 & 2 & $50 \%$ & 0.09 & -0.81 & 1.50 & $\$$ & 536 \\
\hline CONSOLID & Eugene McGrath & 4 & 2 & $50 \%$ & -0.01 & -0.34 & 1.75 & $\$$ & 412 \\
\hline
\end{tabular}


Panel B: Ranked by Above Industry Compensation

$\begin{array}{cllcc}\text { Rank } & \text { Firm } & \text { CEO } & \begin{array}{c}\text { Adjusted } \\ \text { Compensation }\end{array} \\ 1 & \text { DISNEY } & \text { Michael Eisner } & \$ & 38,109 \\ 2 & \text { EXXON MO } & \text { Lee Raymond } & \$ & 19,786 \\ 3 & \text { AT\&T CORP } & \text { C. Armstrong } & \$ & 13,470 \\ 4 & \text { AT\&T CORP } & \text { Robert Allen } & \$ & 6,833 \\ 5 & \text { KIMBERLY } & \text { Wayne Sanders } & \$ & 5,606 \\ 6 & \text { VERIZON } & \text { Raymond Smith } & \$ & 5,286 \\ 7 & \text { UNITED TECH } & \text { George David } & \$ & 5,057 \\ 8 & \text { CENTERPO } & \text { Don Jordan } & \$ & 5,022 \\ 9 & \text { UNION PA } & \text { Drew Lewis } & \$ & 4,916 \\ 10 & \text { AQUILA } & \text { Richard Green J } & \$ & 3,138 \\ 11 & \text { GANNETT } & \text { John Curley } & \$ & 3,100 \\ 12 & \text { FPL GROUP } & \text { James Broadhe } & \$ & 3,069 \\ 13 & \text { DOMINION } & \text { Thos. Capps } & \$ & 2,808 \\ 14 & \text { AVERY DEN } & \text { Charles Miller } & \$ & 2,407 \\ 15 & \text { NATIONAL } & \text { Bernard Kennedy } & \$ & 2,385\end{array}$

$\underline{\text { Panel C: Ranked by declines in ROA }}$

$\begin{array}{llc}\text { KIMBERLY } & \text { Wayne Sanders } & \begin{array}{c}\text { Industry } \\ \text { Adjusted ROA } \\ \text { declines }\end{array} \\ \text { AT\&T COR } & \text { Robert Allen } & -11.08 \\ \text { GANNETT } & \text { John Curley } & -7.74 \\ \text { EXXON MOBILE } & \text { Lee Raymond } & -5.74 \\ \text { DISNEY } & \text { Michael Eisner } & -5.28 \\ \text { TXU CORP } & \text { Erle Nye } & -5.09 \\ \text { AT\&T CORP } & \text { C. Armstrong } & -4.77 \\ \text { SONOCO } & \text { Charles Coker } & -4.17 \\ \text { NATIONAL } & \text { Bernard Kennedy } & -2.93 \\ \text { CENTERPO } & \text { Don Jordan } & -2.88 \\ \text { VERIZON } & \text { Raymond Smith } & -2.76 \\ \text { AQUILA I } & \text { Richard Green J } & -2.45 \\ \text { UNION PA } & \text { Drew Lewis } & -2.17 \\ \text { DUKE ENRGY } & \text { Richard Priory } & -2.07 \\ \text { PACIFICO } & \text { Frederi Buckman } & -2.03\end{array}$




\section{Appendix B \\ Performance and Compensation Details for Highly Paid CEOs in Large Firms with High Environmental Constraints}

This table reports compensation and performance data from a set of firms in which CEO pay is negatively related to skill. We first identify large firms that operate in environments characterized by high constraint on managerial discretion. We then report detailed information on the worst performers in this group of firms - that is, CEOs that (1) appear at least 3 times in our sample; (2) and under whom firm performance declined at least $50 \%$ of the time. In Panel A, the remaining CEOs are then ranked by the fraction of years in decline. Panel B ranks them by the amount by which their salary exceeds their industry compensation (on average) and Panel $\mathrm{C}$ by the sum of the firm's decline in ROA under their control. Executive compensation data is from Execucomp and firm data is from Compustat and CRSP.

\begin{tabular}{|c|c|c|c|c|c|c|c|c|c|}
\hline Firm & CEO & $\begin{array}{l}\text { Years } \\
\text { in } \\
\text { Sample }\end{array}$ & $\begin{array}{c}\text { Years } \\
\text { Industry } \\
\text { Adjusted } \\
\text { ROA } \\
\text { Declined }\end{array}$ & $\begin{array}{c}\% \\
\text { declined }\end{array}$ & $\begin{array}{l}\text { Average } \\
\text { Change } \\
\text { in ROA }\end{array}$ & $\begin{array}{l}\text { Industry } \\
\text { Adjusted } \\
\text { ROA } \\
\text { declines e }\end{array}$ & $\begin{array}{c}\text { Average } \\
\text { Difference } \\
\text { between Pay } \\
\text { and } \\
\text { Performance } \\
\text { Quintiles }\end{array}$ & \multicolumn{2}{|c|}{$\begin{array}{c}\text { Average } \\
\text { Industry } \\
\text { Adjusted } \\
\text { Compensation }\end{array}$} \\
\hline CENTERPO & Don Jordan & 5 & 5 & $100 \%$ & -0.60 & -3.01 & 2.60 & $\$$ & 4,484 \\
\hline DANA COR & Joseph Magliochetti & 3 & 3 & $100 \%$ & -0.97 & -2.92 & 3.00 & $\$$ & 2,020 \\
\hline GREAT AT & James Wood & 3 & 3 & $100 \%$ & -1.07 & -3.21 & 0.67 & $\$$ & 334 \\
\hline ANADARKO & Robert Allison & 6 & 5 & $83 \%$ & -0.65 & -4.23 & 2.33 & $\$$ & 5,819 \\
\hline PHELPS D & Douglas Yearley & 6 & 5 & $83 \%$ & -1.02 & -11.74 & 1.83 & $\$$ & 2,801 \\
\hline HALLIBURTON & Richard Cheney & 5 & 4 & $80 \%$ & -1.16 & -7.60 & 2.60 & $\$$ & 3,297 \\
\hline DOMINION & Thos. Capps & 5 & 4 & $80 \%$ & 0.00 & -0.80 & 1.80 & $\$$ & 2,808 \\
\hline AT\&T CORP & Robert Allen & 4 & 3 & $75 \%$ & 0.11 & -7.74 & 2.00 & $\$$ & 6,833 \\
\hline NOBLE CO & James Day & 4 & 3 & $75 \%$ & -0.19 & -11.09 & 3.25 & $\$$ & 5,404 \\
\hline VERIZON & Raymond Smith & 4 & 3 & $75 \%$ & -0.24 & -2.76 & 2.25 & $\$$ & 5,286 \\
\hline CNF INC & Gregory Quesnel & 4 & 3 & $75 \%$ & -3.50 & -15.56 & 2.25 & $\$$ & 3,115 \\
\hline NORTHWEST & John Dasburg & 4 & 3 & $75 \%$ & -0.65 & -8.06 & 2.50 & $\$$ & 2,563 \\
\hline SONAT IN & Ronald Kuehn, & 4 & 3 & $75 \%$ & -0.61 & -3.09 & 1.50 & $\$$ & 1,760 \\
\hline SONOCO & Charles Coker & 4 & 3 & $75 \%$ & -0.90 & -4.17 & 1.25 & $\$$ & 1,705 \\
\hline NIAGARA & William Davis & 4 & 3 & $75 \%$ & -0.26 & -2.24 & 0.50 & $\$$ & 608 \\
\hline INCO LTD & Michael Sopko & 4 & 3 & $75 \%$ & -0.21 & -2.86 & 2.25 & $\$$ & 503 \\
\hline ALASKA AIR & John Kelly & 4 & 3 & $75 \%$ & -1.10 & -5.18 & 0.75 & $\$$ & 44 \\
\hline MAXXAM I & Charles Hurwitz & 4 & 3 & $75 \%$ & -3.18 & -16.64 & 2.25 & $\$$ & (416) \\
\hline CSX CORP & John Snow & 6 & 4 & $67 \%$ & -0.27 & -3.45 & 3.17 & $\$$ & 9,099 \\
\hline INTL PAP & John Dillon & 6 & 4 & $67 \%$ & -0.40 & -8.19 & 2.83 & $\$$ & 5,544 \\
\hline EDISON I & John Bryson & 6 & 4 & $67 \%$ & -0.05 & -0.80 & 2.50 & $\$$ & 1,427 \\
\hline COVANTA & R. Ablon & 6 & 4 & $67 \%$ & -0.31 & -6.36 & 0.50 & $\$$ & 953 \\
\hline CONOCOPH & J. Mulva & 3 & 2 & $67 \%$ & -0.77 & -3.16 & 1.00 & $\$$ & 16,376 \\
\hline MIDAMERI & David Sokol & 3 & 2 & $67 \%$ & -0.33 & -1.53 & 2.33 & $\$$ & 13,612 \\
\hline AMR CORP & Donald Carty & 3 & 2 & $67 \%$ & -2.18 & -7.24 & 3.33 & $\$$ & 9,102 \\
\hline UNION PA & Drew Lewis & 3 & 2 & $67 \%$ & -0.49 & -2.17 & 2.67 & $\$$ & 4,916 \\
\hline AMR CORP & Robert Crandal & 3 & 2 & $67 \%$ & 0.46 & -1.72 & 3.33 & $\$$ & 4,912 \\
\hline TENNECO & Dana Mead & 3 & 2 & $67 \%$ & -2.47 & -8.67 & 2.67 & $\$$ & 4,715 \\
\hline ALUMAXI & Allen Born & 3 & 2 & $67 \%$ & -0.81 & -5.84 & 2.67 & $\$$ & 4,529 \\
\hline MARRIOTT & John Marriot & 3 & 2 & $67 \%$ & -1.05 & -3.91 & 2.67 & $\$$ & 4,186 \\
\hline KNIGHT-RID & P. Ridder & 3 & 2 & $67 \%$ & -0.09 & -0.35 & 1.33 & $\$$ & 2,661 \\
\hline PRECISIO & William McCormi & 3 & 2 & $67 \%$ & -0.69 & -3.86 & 1.33 & $\$$ & 2,537 \\
\hline KINDER MORG & Larry Hall & 3 & 2 & $67 \%$ & -0.19 & -1.76 & 1.00 & $\$$ & 2,094 \\
\hline
\end{tabular}




\begin{tabular}{|c|c|c|c|c|c|c|c|c|c|c|}
\hline 34 & CHAMPION & Andrew Sigler & 3 & 2 & $67 \%$ & -0.11 & -4.09 & 2.67 & $\$$ & 2,016 \\
\hline 35 & DUKE ENRGY & Richard Priory & 3 & 2 & $67 \%$ & -0.49 & -2.07 & 1.67 & $\$$ & 1,939 \\
\hline 36 & AMERITEC & Richard Notebae & 3 & 2 & $67 \%$ & 0.21 & -2.18 & 0.00 & $\$$ & 1,781 \\
\hline 37 & GENERAL & James Mellor & 3 & 2 & $67 \%$ & -1.04 & -4.00 & 1.67 & $\$$ & 1,759 \\
\hline 38 & ARMCO IN & James Will & 3 & 2 & $67 \%$ & -0.95 & -4.54 & 2.33 & $\$$ & 1,267 \\
\hline 39 & STONE CO & Roger Stone & 3 & 2 & $67 \%$ & -2.11 & -7.56 & 2.33 & $\$$ & 953 \\
\hline 40 & UNION CA & W. McClell & 3 & 2 & $67 \%$ & -0.54 & -4.47 & 1.33 & $\$$ & 743 \\
\hline 41 & GPU INC & James Leva & 3 & 2 & $67 \%$ & -0.18 & -2.35 & 2.00 & $\$$ & 272 \\
\hline 42 & NEW ENGL & John Rowe & 3 & 2 & $67 \%$ & 0.01 & -0.08 & 1.33 & $\$$ & 173 \\
\hline 43 & HILTON & Stephen Bollenb & 3 & 2 & $67 \%$ & -0.94 & -3.90 & 1.00 & $\$$ & (151) \\
\hline 44 & DPL INC & Allen Hill & 3 & 2 & $67 \%$ & -0.56 & -1.75 & 0.33 & $\$$ & (331) \\
\hline 45 & KIMBERLY & Wayne Sanders & 8 & 5 & $63 \%$ & 0.24 & -11.08 & 1.63 & $\$$ & 5,606 \\
\hline 46 & NATIONAL & Bernard Kennedy & 8 & 5 & $63 \%$ & -0.18 & -4.58 & 2.50 & $\$$ & 2,971 \\
\hline 47 & HONEYWELL & Lawrenc Bossidy & 5 & 3 & $60 \%$ & -0.16 & -1.69 & 3.00 & $\$$ & 14,692 \\
\hline 48 & AK STEEL & Richard Wardrop & 5 & 3 & $60 \%$ & -0.21 & -2.82 & 2.60 & $\$$ & 7,750 \\
\hline 49 & ALLTEL C & Joe Ford & 5 & 3 & $60 \%$ & 0.60 & -5.04 & 1.40 & $\$$ & 4,702 \\
\hline 50 & EATON CO & Stephen Hardis & 5 & 3 & $60 \%$ & -0.09 & -3.57 & 2.00 & $\$$ & 4,076 \\
\hline 51 & GENERAL & Nichola Chabraj & 5 & 3 & $60 \%$ & 0.54 & -3.15 & 2.20 & $\$$ & 2,933 \\
\hline 52 & ALCAN IN & Jacques Bougie & 5 & 3 & $60 \%$ & -0.25 & -2.19 & 1.60 & $\$$ & 2,903 \\
\hline 53 & NORFOLK & David Goode & 5 & 3 & $60 \%$ & -0.44 & -2.46 & 2.40 & $\$$ & 2,846 \\
\hline 54 & BETHLEHEM & Curtis Barnett & 5 & 3 & $60 \%$ & 1.19 & -3.42 & 2.40 & $\$$ & 1,164 \\
\hline 55 & PACIFICORP & Frederi Buckman & 5 & 3 & $60 \%$ & -0.35 & -2.03 & 2.20 & $\$$ & 1,016 \\
\hline 56 & UNOCAL C & Roger Beach & 5 & 3 & $60 \%$ & -0.34 & -4.76 & 1.60 & $\$$ & 615 \\
\hline 57 & PINNACLE & Richard Snell & 5 & 3 & $60 \%$ & 0.01 & -0.52 & 1.20 & $\$$ & 363 \\
\hline 58 & FPL GROU & James Broadhead & 7 & 4 & $57 \%$ & 0.02 & -0.71 & 2.29 & $\$$ & 7,981 \\
\hline 59 & MARATHON & Thomas Usher & 7 & 4 & $57 \%$ & 0.03 & -9.61 & 2.14 & $\$$ & 7,944 \\
\hline 60 & TOSCO CO & Thomas O'Malle & 7 & 4 & $57 \%$ & -0.48 & -7.33 & 1.43 & $\$$ & 5,951 \\
\hline 61 & CONSOLID & Eugene McGrath & 7 & 4 & $57 \%$ & -0.04 & -1.13 & 1.86 & $\$$ & 2,557 \\
\hline 62 & TXU CORP & Erle Nye & 7 & 4 & $57 \%$ & 0.09 & -5.09 & 1.71 & $\$$ & 1,009 \\
\hline 63 & OCCIDENT & Ray Irani & 8 & 4 & $50 \%$ & 0.34 & -6.59 & 2.50 & $\$$ & 20,812 \\
\hline 64 & EXXON & Lee Raymond & 8 & 4 & $50 \%$ & -0.06 & -5.74 & 1.75 & $\$$ & 19,786 \\
\hline 65 & COMCAST & Ralph Roberts & 8 & 4 & $50 \%$ & 0.13 & -32.15 & 1.88 & $\$$ & 11,766 \\
\hline 66 & UNITED TECH & George David & 8 & 4 & $50 \%$ & 0.35 & -1.89 & 2.63 & $\$$ & 7,169 \\
\hline 67 & AQUILA I & Richard Green J & 8 & 4 & $50 \%$ & -0.10 & -2.45 & 2.63 & $\$$ & 4,295 \\
\hline 68 & DISNEY & Michael Eisner & 6 & 3 & $50 \%$ & -0.10 & -5.28 & 0.50 & $\$$ & 38,109 \\
\hline 69 & WORLDCOM & Bernard Ebbers & 6 & 3 & $50 \%$ & 0.31 & -18.94 & 1.33 & $\$$ & 23,882 \\
\hline 70 & EL PASO & William Wise & 6 & 3 & $50 \%$ & -0.51 & -6.20 & 2.00 & $\$$ & 10,887 \\
\hline
\end{tabular}


Panel B: Ranked by Above Industry Compensation

Average Industry Adjusted

$\begin{array}{rllrr}\text { Rank } & \text { Firm } & \text { CEO } & \text { Compensation } \\ 1 & \text { NABORS } & \text { Eugene Isenberg } & \$ & 53,945 \\ 2 & \text { DISNEY } & \text { Michael Eisner } & \$ & 38,109 \\ 3 & \text { WORLDCOM } & \text { Bernard Ebbers } & \$ & 23,882 \\ 4 & \text { OCCIDENT } & \text { Ray Irani } & \$ & 20,812 \\ 5 & \text { EXXON MO } & \text { Lee Raymond } & \$ & 19,786 \\ 6 & \text { CONOCOPH } & \text { J. Mulva } & \$ & 16,376 \\ 7 & \text { HONEYWEL } & \text { Lawrenc Bossidy } & \$ & 14,692 \\ 8 & \text { MIDAMERI } & \text { David Sokol } & \$ & 13,612 \\ 9 & \text { AT\&T COR } & \text { C. Armstrong } & \$ & 12,436 \\ 10 & \text { COMCAST } & \text { Ralph Roberts } & \$ & 11,766 \\ 11 & \text { EL PASO } & \text { William Wise } & \$ & 10,887 \\ 12 & \text { DELTA AI } & \text { Leo Mullin } & \$ & 10,801 \\ 13 & \text { CHRYSLER } & \text { Robert Eaton } & \$ & 9,335 \\ 14 & \text { GENERAL } & \text { John Smith } & \$ & 9,227 \\ 15 & \text { AMR CORP } & \text { Donald Carty } & \$ & 9,102 \\ 16 & \text { CSX CORP } & \text { John Snow } & \$ & 9,099 \\ 17 & \text { FPL GROU } & \text { James Broadhead } & \$ & 7,981 \\ 18 & \text { MARATHON } & \text { Thomas Usher } & \$ & 7,944 \\ 19 & \text { AK STEEL } & \text { Richard Wardrop } & \$ & 7,750 \\ 20 & \text { UNITED TECH } & \text { George David } & \$ & 7,169 \\ 21 & \text { AT\&T COR } & \text { Robert Allen } & \$ & 6,833 \\ 22 & \text { TOSCO CO } & \text { Thomas O'Malle } & \$ & 5,951 \\ 23 & \text { BOEING C } & \text { Philip Condit } & \$ & 5,836 \\ 24 & \text { ANADARKO } & \text { Robert Allison } & \$ & 5,819 \\ 25 & \text { UNITED S } & \text { Thomas Usher } & \$ & 5,810 \\ 26 & \text { KIMBERLY } & \text { Wayne Sanders } & \$ & 5,606 \\ 27 & \text { INTL PAP } & \text { John Dillon } & \$ & 5,544 \\ 28 & \text { NOBLE CO } & \text { James Day } & \$ & 5,404 \\ 29 & \text { CORNING } & \text { Roger Ackerman } & \$ & 5,387 \\ 30 & \text { VERIZON } & \text { Raymond Smith } & \$ & 5,286 \\ 31 & \text { UNION PA } & \text { Drew Lewis } & \$ & 4,916 \\ 32 & \text { AMR CORP } & \text { Robert Crandal } & \$ & 4,912 \\ 33 & \text { TENNECO } & \text { Dana Mead } & \$ & 4,715 \\ 34 & \text { ALLTEL C } & \text { Joe Ford } & \$ & 4,702 \\ 35 & \text { ALUMAXI } & \text { Allen Born } & \$ & 4,529 \\ 36 & \text { CENTERPO } & \text { Don Jordan } & \$ & 4,484 \\ 37 & \text { AQUILA I } & \text { Richard Green J } & \$ & 4,295 \\ 38 & \text { MARRIOTT } & \text { John Marriot } & \$ & 4,186 \\ 39 & \text { EATON CO } & \text { Stephen Hardis } & \$ & 4,076 \\ 40 & \text { AMERADA } & \text { John Hess } & \$ & 4,063 \\ 41 & \text { SCHLUMBE } & \text { D. Baird } & \$ & 3,461 \\ 42 & \text { HALLIBURTON } & \text { Richard Cheney } & \$ & 3,297\end{array}$

Panel C: Ranked by decline in ROA

Industry

Adjusted R(

declines

$\begin{array}{lll}\text { COMCAST } & \text { Ralph Roberts } & -32.15 \\ \text { WORLDCOM } & \text { Bernard Ebbers } & -18.94 \\ \text { MAXXAM I } & \text { Charles Hurwitz } & -16.64 \\ \text { CNF INC } & \text { Gregory Quesnel } & -15.56 \\ \text { PHELPS } & \text { Douglas Yearley } & -11.74 \\ \text { NOBLE CO } & \text { James Day } & -11.09 \\ \text { KIMBERLY } & \text { Wayne Sanders } & -11.08 \\ \text { MARATHON } & \text { Thomas Usher } & -9.61 \\ \text { NABORS } & \text { Eugene Isenberg } & -9.37 \\ \text { TENNECO } & \text { Dana Mead } & -8.67 \\ \text { INTL PAP } & \text { John Dillon } & -8.19 \\ \text { NORTHWES } & \text { John Dasburg } & -8.06 \\ \text { AT\&T CORP } & \text { Robert Allen } & -7.74 \\ \text { HALLIBURTON } & \text { Richard Cheney } & -7.60 \\ \text { STONE CO } & \text { Roger Stone } & -7.56 \\ \text { DELTA AI } & \text { Leo Mullin } & -7.47 \\ \text { TOSCO CO } & \text { Thomas O'Malle } & -7.33 \\ \text { AMR CORP } & \text { Donald Carty } & -7.24 \\ \text { GANNETT } & \text { John Curley } & -6.85 \\ \text { BOEING C } & \text { Philip Condit } & -6.71 \\ \text { OCCIDENT } & \text { Ray Irani } & -6.59 \\ \text { BOISE CA } & \text { George Harad } & -6.53 \\ \text { COVANTA } & \text { R. Ablon } & -6.36 \\ \text { EL PASO } & \text { William Wise } & -6.20 \\ \text { AMERADA } & \text { John Hess } & -6.12 \\ \text { ALUMAX I } & \text { Allen Born } & -5.84 \\ \text { EXXON } & \text { Lee Raymond } & -5.74 \\ \text { DISNEY } & \text { Michael Eisner } & -5.28 \\ \text { ALASKA AIR } & \text { John Kelly } & -5.18 \\ \text { OLIN COR } & \text { Donald Griffin } & -5.14 \\ \text { TXU CORP } & \text { Erle Nye } & -5.09 \\ \text { CORNING } & \text { Roger Ackerman } & -5.09 \\ \text { ALLTEL C } & \text { Joe Ford } & -5.04 \\ \text { AT\&T COR } & \text { C. Armstrong } & -4.77 \\ \text { UNOCAL C } & \text { Roger Beach } & -4.76 \\ \text { NATIONAL } & \text { Bernard Kennedy } & -4.58 \\ \text { ARMCO IN } & \text { James Will } & -4.54 \\ \text { UNION CA } & \text { W. McClell } & -4.47 \\ \text { ANADARKO } & \text { Robert Allison } & -4.23 \\ \text { CHRYSLER } & \text { Robert Eaton } & -4.23 \\ \text { SONOCO } & \text { Charles Coker } & -4.17 \\ \text { CHAMPION } & \text { Andrew Sigler } & -4.09\end{array}$

